\title{
Avifaunal inventory of the Amazonian savannas and adjacent habitats of the Monte Alegre region (Pará, Brazil), with comments on biogeography and conservation
}

\section{Levantamento da avifauna das savanas amazônicas e de habitats adjacentes da região de Monte Alegre (Pará, Brasil), com comentários sobre biogeografia e conservação}

\author{
Marcelo Ferreira de Vasconcelos', Sidnei de Melo Dantas", José Maria Cardoso da SilvallI \\ 'Pontifícia Universidade Católica de Minas Gerais. Belo Horizonte, Minas Gerais, Brasil \\ "Museu Paraense Emílio Goeldi. Coordenação de Zoologia. Belém, Pará, Brasil \\ III Conservação Internacional do Brasil. Belém, Pará, Brasil
}

\begin{abstract}
Knowledge of the avifaunal composition of Amazonian savannas is important in facilitating a greater understanding of the patterns of evolution of the regional biota. Despite this, this vegetation type has been poorly sampled in comparison to adjacent rainforest habitats. The aim of this paper is to provide an avifaunal inventory of the savannas and other adjacent habitats of Monte Alegre, on the left bank of Amazon River, northwestern Pará, Brazil. Our survey is based both on our own fieldwork and on previously-collected specimens deposited in museums. A total of 300 bird species have been recorded in the region. Ninety-four species (31.3\%) were restricted to a single habitat type, indicating that habitat heterogeneity is important to the overall species richness. Despite the fact that the Monte Alegre savannas present typical species restricted to this habitat, several open-country birds that occur in larger savanna areas located on the borders of Amazonia (along the Atlantic coast and close to the 'cerrado' boundaries) were not recorded in this area. Although Monte Alegre is species impoverished relative to other savanna regions in the Amazon basin, the Monte Alegre savannas shelter the Sulfur-breasted Parakeet (Aratinga maculata), a vulnerable species in Pará state that is only known from the Guianan area of endemism (Aleixo et al., 2011). We also comment on biogeography, taxonomy, noteworthy records, natural history and conservation of the regional avifauna.
\end{abstract}

Keywords: Avifaunal survey. Amazonian savannas. Biogeography. Natural history. Conservation. Aratinga maculata.

Resumo: $\bigcirc$ conhecimento sobre a composição da avifauna das savanas amazônicas é muito importante para o entendimento de padrões da evolução da biota regional. Entretanto, este tipo de vegetação foi pouco amostrado em comparação com áreas de florestas adjacentes. O objetivo deste trabalho é apresentar um levantamento da avifauna das savanas e de habitats adjacentes de Monte Alegre, na margem esquerda do rio Amazonas, noroeste do Pará, Brasil. Nossa pesquisa baseou-se em nossos trabalhos de campo e em exemplares coletados anteriormente e depositados em museus. Um total de 300 espécies de aves foi registrado na região. Noventa e quatro espécies (31,3\%) estiveram restritas a um único tipo de habitat, indicando que a heterogeneidade de habitats é importante para a riqueza geral de espécies. Apesar de as savanas de Monte Alegre apresentarem espécies típicas deste habitat, faltam outras aves de ambientes abertos que ocorrem em áreas maiores de savana localizadas nas bordas da Amazônia, especialmente ao longo da costa Atlântica ou próximo aos limites do cerrado. Embora a avifauna de Monte Alegre seja relativamente pobre em comparação com outras áreas de savanas na bacia amazônica, as savanas de Monte Alegre abrigam o cacaué (Aratinga maculata), uma espécie vulnerável no estado do Pará, com distribuição restrita à área de endemismo Guiana (Aleixo et al., 2011). Também comentamos sobre biogeografia, taxonomia, registros notáveis, história natural e conservação da avifauna regional.

Palavras-chave: Levantamento de avifauna. Savanas amazônicas. Biogeografia. História natural. Conservação. Aratinga maculata.

VASCONCELOS, M. F., S. M. DANTAS \& J. M. C. SILVA, 2011. Avifaunal inventory of the Amazonian savannas and adjacent habitats of the Monte Alegre region (Pará, Brazil), with comments on biogeography and conservation. Boletim do Museu Paraense Emílio Goeldi. Ciências Naturais 6(2): 119-145.

Autor para correspondência: Marcelo Ferreira de Vasconcelos. Pontifícia Universidade Católica de Minas Gerais. Pós-graduação em Zoologia de Vertebrados e Museu de Ciências Naturais. Avenida Dom José Gaspar, 500, Prédio 41, Coração Eucarístico. Belo Horizonte, MG, Brasil. CEP 30535-610 (mfvasconcelos@gmail.com).

Recebido em 16/03/2010

Aprovado em 28/06/2011

Responsabilidade editorial: Marinus Hoogmoed

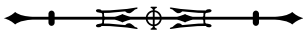




\section{INTRODUCTION}

Patches of savannas and other open vegetation biotypes are found nested in extensive areas of rainforest in Brazilian Amazonia (Prance, 1978; Pires \& Prance, 1985; Sanaiotti et al., 1997; Miranda \& Absy, 2000; Vicentini, 2004; Gottsberger \& Silberbauer-Gottsberger, 2006; Pennington et al., 2006; Ratter et al., 2006; Magnusson et al., 2008). Amazonian savannas occur mainly on poor, sandy soils on both banks of the Amazon River (Gottsberger \& Silberbauer-Gottsberger, 2006; Pennington et al., 2006; Ratter et al., 2006). Important sites include those in the states of Roraima, Amapá, Amazonas and Pará (AndradeLima, 1958; Miranda, 1993; Miranda \& Absy, 2000; Gottsberger \& Silberbauer-Gottsberger, 2006; Pennington et al., 2006; Ratter et al., 2006; Magnusson et al., 2008).

Knowledge of the avifauna composition of Amazonian open habitats is crucial to understanding patterns of distribution and evolution of birds in South America (E. Snethlage, 1909; Haffer, 1967, 1969, 1974, 1985, 1987; Silva, 1995; Silva et al., 1997; Silva \& Bates, 2002; Bates et al., 2003; Robbins et al., 2004; Mittermeier et al., 2010). Amazonian savannas are considered present-day 'refugia' of a widespread open vegetation type that probably expanded across the Amazonian belt of low precipitation during dry phases of the Cenozoic (Haffer, 1967, 1969, 1974; Prance, 1978, 1987; Haffer \& Prance, 2001; Ab'Saber, 2002). Despite their importance for the Amazonian biogeography, these areas have been poorly sampled in comparison to rainforest sites throughout the Amazonian region, and published avifaunal inventories have focused on savannas in the Sipaliwini region (Suriname) and in the Brazilian states of Roraima, Amazonas, Pará, Amapá and Rondônia (Henriques \& Oren, 1997; Silva et al., 1997; Sanaiotti \& Cintra, 2001; Naka et al., 2006; Aleixo \& Poletto, 2007; Santos \& Silva, 2007; Mittermeier et al., 2010; Aleixo et al., 2011).

Monte Alegre is located on the left (northern) bank of the Amazon River, northwestern Pará, Brazil. The region is located on the southern border of the Guianan area of endemism, a well known area of avian endemism (see Cracraft, 1985). Monte Alegre savannas are isolated from other large savanna areas (e. g., 'cerrado', Amapá, Llanos, Roraima-Rupununi, Sipaliwini) by hundreds of kilometers of Amazonian rainforest, but are only separated by the Amazon River from other savanna enclaves on the southern bank (Alter do Chão) (Figure 1).

Ornithological surveys of Monte Alegre started in the $19^{\text {th }}$ century, when F. W. Sieber collected some specimens in this region, between 1801 and 1812 (Pinto, 1979). These specimens were deposited in the Museum für Naturkunde (ZMB), Berlin (Pinto, 1979). The famous British naturalist A. R. Wallace also explored the area in 1849 and collected a few specimens that have been deposited in the British Museum of Natural History (BMNH), Tring (Sclater \& Salvin, 1867; Pinto, 1979). Later, more detailed ornithological collections were made by E. Snethlage, O. Martins, A. Costa, J. de Sá, J. Anthero and F. J. José during the first two decades of the $20^{\text {th }}$ century (E. Snethlage, 1906, 1907, 1914; H. Snethlage, 1930; Miranda-Ribeiro, 1938). During these expeditions, over 720 specimens were collected and deposited in the Museu Paraense Emílio Goeldi (MPEG), Belém. Between 1917 and 1920, F. Q. Lima and E. Garbe, working for the Museu Paulista (currently Museu de Zoologia da Universidade de São Paulo, MZUSP), also collected specimens in Monte Alegre (Pinto, 1944, 1945). Shortly after these expeditions, C. Lako collected birds in the Monte Alegre region (Maicuru River) in 1928 and 1929 (Paynter \& Traylor, 1991; Silveira et al., 2005). These specimens were deposited in the Field Museum of Natural History (FMNH) and in the American Museum of Natural History (AMNH) (Paynter \& Traylor, 1991; Silveira et al., 2005). A. M. Olalla also visited the region in 1936, when he collected specimens that were sent to the FMNH (Paynter \& Traylor, 1991). Recently, a new species of parakeet (Psittacidae), Aratinga maculata (Sulfur-breasted Parakeet), was described from Monte Alegre (Silveira et al., 2005) (the species was described as Aratinga pintoi but this is now considered a junior synonym of Aratinga maculata, see Nemésio \& Rasmussen, 2009), and the region became better known among ornithologists and 


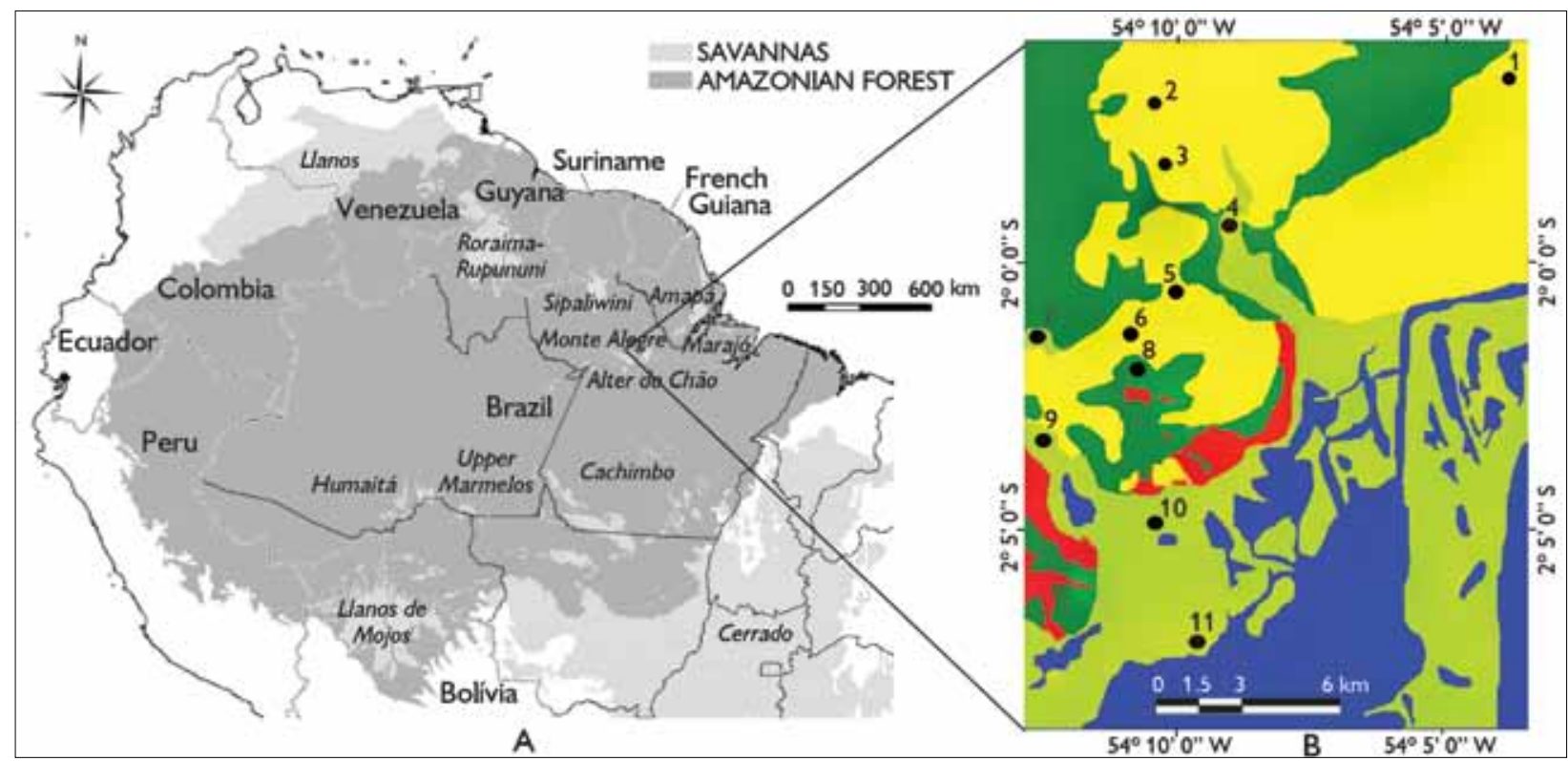

Figure 1. Study area. A: Map of northern South America showing the main savanna areas referenced in the text. Adapted from Aleixo \& Poletto (2007). B: Main habitat types and surveyed sites in the Monte Alegre region. Habitats: savanna (white); flooded forest and 'campo de várzea' (light gray); 'terra firme' forest and 'campinarana' (gray); disturbed areas (dark gray); lakes and rivers (black). Sites: $1=$ km 4 of road PA-423; 2 = Campo do Desterro; 3 = Colônia do Ererê; 4 = Igarapé do Ererê; 5 = Santana; 6 = Serra do Ererê; $7=$ Aruchi; 8 = Ilha Grande; 9 = Mutuacá; 10 = Lago da Conceição; 11 = Margin of the Amazon River. Adapted from Pereira et al. (2003).

birdwatchers (Silveira, 2005; Balchin, 2006). Although this region has been inventoried by generations of ornithologists, old collections from Monte Alegre have never been studied in detail and the area lacks an ornithological checklist. Thus, the aim of this paper is to provide an avifaunal inventory of the Monte Alegre region, based on our own fieldwork and on specimens held in museums. We also comment on biogeography, taxonomy, noteworthy records, natural history and conservation of the avifauna.

\section{MATERIAL AND METHODS}

\section{STUDY AREA}

Our study was located in the Monte Alegre region (between $01^{\circ} 56^{\prime}$ and $02^{\circ} 07^{\prime} \mathrm{S}$, and $54^{\circ} 03^{\prime}$ and $54^{\circ} 13^{\prime} \mathrm{W}$ ), state of Pará, northern Brazil (Figure 1). The elevation ranges from $3 \mathrm{~m}$ to $400 \mathrm{~m}$ (Pastana, 1999) and the climate is hot and humid (type Awi of the Köppen classification) (Ayoade, 1998). Temperatures vary between monthly averages of $25.7^{\circ}$ and $27^{\circ} \mathrm{C}$ (Oliveira-Júnior et al., 1999) and mean annual precipitation is $1,678 \mathrm{~mm}$ (Moraes et al., 2005). Rainfall peaks in April and the rainy season is concentrated between February and May, when monthly precipitation surpasses $200 \mathrm{~mm}$. The dry season is between September and October, when monthly rainfall averages are lower than 50 mm (Oliveira-Júnior et al., 1999).

Savanna vegetation (locally named 'coberto') occurs generally on sandy or rocky soils, with the presence of a few species of grasses and herbs and a very inconspicuous litter layer (Figure 2A and Figure 2B). Shrubby-arboreal vegetation is primarily represented by sparse individuals of the following species: Curatella americana, Qualea grandiflora, Salvertia convallariodora, Sclerolobium paniculatum, Anacardium occidentale, Palicourea rigida and Tocoyena formosa, generally varying from 1 to $4 \mathrm{~m}$ in height. At Serra do Ererê (02 01' 16" S 54 10' 55" W), a mountainous locality in this region (elevation: $220 \mathrm{~m}$ ), savanna occurs mainly over and between rock

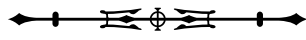




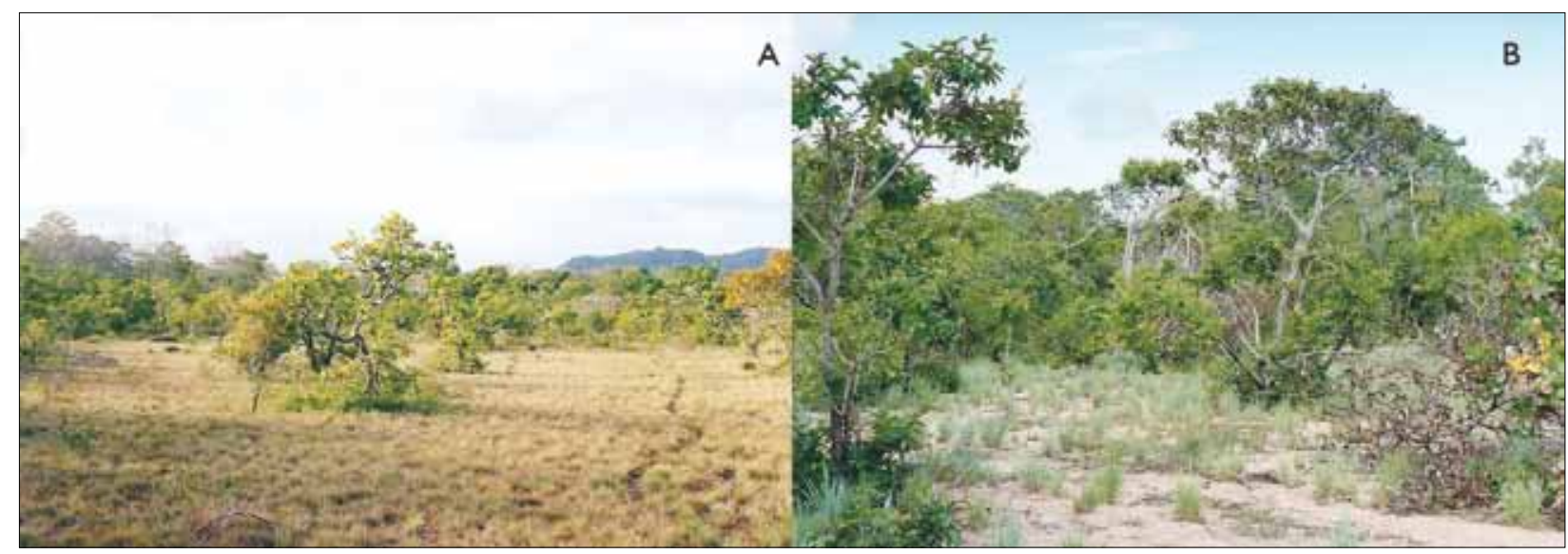

Figure 2. Typical savanna sites in Monte Alegre. A: Savannas on gravel substrate with tortuous trees and dense grass layer, showing Serra do Ererê on the background. B: Savannas on sandy soil with a sparse grass layer. Photos: M. F. Vasconcelos, 1999.

outcrops, with shrubs of Cereus sp., Phyllodendron sp. and Norantea guianensis. In this area there are also sparse shrubby-arboreal individuals of Aspidosperma sp., Byrsonima crassifolia, Q. grandiflora and S. convallariodora growing on sandy or rocky soils. Some of these trees are parasitized by a mistletoe (Psittachanthus sp.) with hummingbird-pollinated flowers (Vasconcelos \& Silva, 2005). For a detailed botanical inventory of the Monte Alegre savannas, see Andrade-Lima (1958).

These savannas are intermixed with patches of 'campinarana', a low-canopy forest growing on sandy soil with trees reaching up to $10 \mathrm{~m}$ in height. These 'campinaranas' are very dense, with a developed understory with tangles of vines and shrubs (mainly Miconia sp.). At some places within the savannas, there are clumps of trees that resemble small patches of 'campinarana', with a denser layer of litter and shrubs of Eugenia sp., Miconia sp. and Cereus sp.

Original 'terra firme' forests ('floresta ombrófila') were extensively cleared and fragmented (Pereira et al., 2003). Several areas originally covered by this vegetation type are now occupied by clumps of an abundant pioneer species of palm tree (Attalea sp.), and the remnant fragments are subject to illegal logging (see below). Typical tree species of those forests are: Aspidosperma desmanthum, Bellucia sp., Geissospermum sericeum, Hymenaea parviflora, Inga micradenia, Licania spp., Myrcia paivae, Nectandra mollis and Protium paniculatum (Garcia et al., unpublished data 2008).

Flooded forests occur along watercourses, usually associated with flooded open habitats ('campos de várzea'), with 'buriti' (Mauritia flexuosa) and 'açaí' (Euterpe oleracea) palm groves. Rivers and lakes also represent important habitats for water birds in the Monte Alegre region.

\section{METHODS}

We made three expeditions to Monte Alegre aiming principally to collect specimens in the savannas. The first expedition was performed by JMCS, MFV and D. C. Pimentel Neto between 2 and 20 January 1999. Specimens were collected with shotguns and mistnets and have been deposited in MPEG and in the ornithological collection of the Department of Zoology, Universidade Federal de Pernambuco (UFPE). Localities sampled during this expedition were: savannas and 'campinaranas' at km 4 of road PA-423 (010 56' 38" S $\left.54^{\circ} 03^{\prime} 45^{\prime \prime} \mathrm{W}\right)$; savannas of Campo do Desterro $\left(01^{\circ}\right.$ $57^{\prime}$ 04" S 54 10' 20" W); savannas and 'terra firme' forest fragments at Colônia do Ererê (010 58' 14" S $54^{\circ}$ 10 ' 01" W); and savannas and 'campinaranas' at Serra

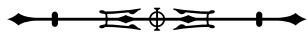


do Ererê (020 01' 16" S 54 10' 55" W). The second expedition was made by SMD and J. N. Santa Brígida, between 21 and 28 September 2006, during a study for the management plan of the Monte Alegre State Park. Fieldwork was conducted in the following localities: a 'terra firme' forest fragment at llha Grande $\left(02^{\circ} 01^{\prime} 55^{\prime}\right.$ " S $\left.54^{\circ} 10^{\prime} 39^{\prime \prime} \mathrm{W}\right)$; flooded forest at Aruchi (02 $01^{\prime} 28^{\prime \prime}$ S 54 12' 33" W); flooded forest at Igarapé do Ererê (010 59' 20" S 54 08' 57" W); 'terra firme' forest and savannas at Colônia do Ererê (02 00' 06" S 54 10' 48" W); savannas at Santana (02 00' 30" S 54 09' 58" W); and savannas at Serra do Ererê (02 $01^{\circ}$ ' 32" S 54 $4^{\circ} 11^{\prime}$ 07 " W). Specimens were collected with mist-nets and deposited in MPEG. The third expedition was made by SMD, between 19 and 23 March 2009, in the following localities: lake at Lago da Conceição (02 04' 54" S $54^{\circ}$ $10^{\prime} 21^{\prime \prime} \mathrm{W}$ ); 'buriti' palm grove at Mutuacá (02 $03^{\prime}$ ' 18" S $\left.54^{\circ} 12^{\prime} 21^{\prime \prime} \mathrm{W}\right)$; and flooded forests along the Amazon River (0207' 08" S 54 09' 36" W). In all expeditions, birds were also photographed and tape-recorded. Recordings will be deposited at the Arquivo Sonoro Prof. Elias Coelho (ASEC), Departamento de Zoologia, Universidade Federal do Rio de Janeiro (UFRJ), Rio de Janeiro, Brazil. Some of these recordings have been archived on the online resource Xeno-Canto (2009).

We also studied old specimens collected in the Monte Alegre region deposited in MPEG and checked the literature (Pinto, 1944; Ruschi, 1951; Silveira et al., 2005) for additional specimens deposited in the following institutions: AMNH, FMNH, MZUSP and Museu Nacional do Rio de Janeiro (MNRJ).

We took notes in the field in which habitat each species was observed. For those recorded exclusively in museums, we classified them by habitat type based on our own field experience and following Ridgely \& Tudor (1989, 1994), Stotz et al. (1996), Cohn-Haft et al. (1997), Borges et al. (2001) and Naka et al. (2006). Systematic order and nomenclature follow those of the Comitê Brasileiro de Registros Ornitológicos (CBRO, 2009).

\section{RESULTS AND DISCUSSION}

\section{AVIFAUNAL SURVEY}

A total of 300 bird species was recorded in the Monte Alegre region (Appendix). Flooded forests and 'terra firme' forests held the highest species richness (146 and 143 species, respectively), followed by 'campinarana' (122 species), savannas (109 species) and 'campos de várzea' (99 species) (Table 1). Disturbed areas and open waterbodies (lakes and rivers) had the lowest species richness (respectively 57 and 54 species, Table 1).

Ninety-four species (31.3\%) were restricted to a single habitat type (Table 1). This shows that habitat heterogeneity is important for the overall species richness (see Cohn-Haft et al., 1997). Similar results were obtained in other surveys of Amazonian savannas intermixed with other vegetation types (Silva et al., 1997; Aleixo \& Poletto, 2007; Santos \& Silva, 2007; Aleixo et al., 2011). Open waterbodies (lakes and rivers) hold the highest percentage of exclusive species (48.1\%), followed by savannas, which presented $18.3 \%$ exclusive species (Table 1). On the other hand, 'campinaranas' showed the lowest percentage of exclusive species (3.3\%), probably because this habitat shelters several birds that also live in other forest types, such as 'terra firme' and flooded forests (Borges, 2004).

Aratinga maculata (Sulfur-breasted Parakeet) was the only species considered to be restricted to the Monte Alegre region (Silveira et al., 2005), although some specimens listed by these authors were taken from Suriname and considered mislabeled. Recently, Mittermeier et al. (2010) collected an additional specimen in the Sipaliwini savanna, confirming its presence in Suriname. More recent records were presented by Aleixo et al. (2011) from Trombetas State Forest, southern part of the Grão Pará Ecological Station and Paru State Forest. Lophornis ornatus (Tufted Coquette) was previously considered by Cracraft (1985) as a Guianan area of endemism endemic, but it also occurs in Cracraft's Parian Montane area of endemism (see map in 
Züchner, 1999) and on the right bank of the Amazon River, in the savannas of Alter do Chão (Sanaiotti \& Cintra, 2001).

Three threatened species were recorded in the region (following Machado et al., 2005; SECTAM, 2006; BirdLife International, 2009): Anodorhynchus hyacinthinus (Hyacinth Macaw) - globally endangered, vulnerable in Brazil and in Pará state; Primolius maracana (Blue-winged Macaw) - near threatened globally and in Brazil, vulnerable in Pará state; and Aratinga maculata (Sulfur-breasted Parakeet) - vulnerable in Pará state, but not yet evaluated by BirdLife International (2009) and by the Brazilian red list.

\section{COMMENTS ON THE BIOGEOGRAPHY OF} THE MONTE ALEGRE SAVANNA AVIFAUNA

It is possible to make some biogeographical comments on the avifauna of the Monte Alegre savannas. For example, Colinus cristatus (Crested Bobwhite) is the only species restricted to the savannas north of the Amazon River found in Monte Alegre (Sick, 1997). On the other hand, 13 savanna species whose ranges in South America are mainly centered on regions located south of Amazonia ('caatinga', 'cerrado' and 'chaco'; following Silva et al., 1997) were recorded at Monte Alegre: Buteo albicaudatus (White-tailed Hawk), Aratinga aurea (Peach-fronted Parakeet), Chordeiles pusillus (Least Nighthawk), Colaptes campestris (Campo Flicker), Formicivora rufa (Rusty-backed Antwren), Lepidocolaptes angustirostris (Narrow-billed Woodcreeper), Elaenia cristata (Plain-crested Elaenia), Suiriri suiriri (Suiriri Flycatcher), Xolmis velatus (Whiterumped Monjita), Tyrannus albogularis (White-throated Kingbird), Tyrannus savana (Fork-tailed Flycatcher), Mimus saturninus (Chalk-browed Mockingbird) and Ammodramus humeralis (Grassland Sparrow). These species exhibit the Peri-Atlantic distribution pattern (following Silva, 1995). This pattern suggests connections between the 'cerrado' region and the northern South American savannas through an Atlantic coast savanna corridor (Silva, 1995; Silva \& Bates, 2002). However, other important species sharing this pattern of distribution occur in coastal savannas (e. g., Marajó Island and Amapá state; see Silva, 1995; Henriques \& Oren, 1997; Silva et al., 1997), but are absent in the Monte Alegre savannas. Examples are: Uropelia campestris (Long-tailed Ground-Dove), Guira guira (Guira Cuckoo), Neothraupis fasciata (White-banded Tanager) and Coryphaspiza melanotis (Black-masked Finch). Thus, it seems that the avifauna of the Monte Alegre savannas have been isolated from other large South American savannas ('cerrado' and Llanos) for a longer period in comparison to coastal savannas, which seem to have had more recent connections to the 'cerrado' (Silva, 1995; Silva et al., 1997; Silva \& Bates, 2002; Bates et al., 2003; Mittermeier et al., 2010). This pattern does not support the presence of a broad savanna corridor across the Amazonian belt of low precipitation, one of the assumptions of the refuge theory (Haffer, 1969, 1974). However, in a recent paper, Haffer \& Prance (2001) stressed that not just savannas were believed to expand and isolate the wet forest 'refugia'. They suggested that other vegetation types of seasonally dry climates (e.g., dry forest, liana forest and bamboo forest) could have been effective barriers to the dispersal of rainforest 'refugia' organisms (see also Pennington et al., 2000). Bonaccorso et al. (2006) modeled potential distributions of 17 species of plants and birds during the Last Glacial Maximum and suggested that past climate changes fragmented rainforest species' ranges but there

Table 1. Bird species richness in habitats of Monte Alegre region.

\begin{tabular}{l|c|c|c}
\hline \multicolumn{1}{c|}{ Habitats } & $\begin{array}{c}\text { Total } \\
\text { species }\end{array}$ & $\begin{array}{c}\text { Exclusive } \\
\text { species }\end{array}$ & $\begin{array}{c}(\%) \\
\text { Exclusive } \\
\text { species }\end{array}$ \\
\hline Flooded forest & 146 & 17 & 11.6 \\
\hline 'Terra firme' forest & 143 & 14 & 9.8 \\
\hline 'Campinarana' & 122 & 4 & 3.3 \\
\hline Savanna & 109 & 20 & 18.3 \\
\hline 'Campo de várzea' & 99 & 11 & 11.1 \\
\hline Man-made, disturbed areas & 57 & 2 & 3.5 \\
\hline $\begin{array}{l}\text { Open waterbodies } \\
\text { (lakes and rivers) }\end{array}$ & 54 & 26 & 48.1 \\
\hline \multicolumn{1}{c|}{ Total } & 300 & 94 & 31.3 \\
\hline
\end{tabular}

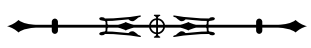


was not a clear pattern for savanna species. These results also do not support the broad expansion of savannas into areas currently covered by Amazonian rainforests. Various other studies show a similar pattern; most notably those based on the pollen record (see Bush \& de Oliveira, 2006 for a recent review).

Furthermore, the relatively small area of Monte Alegre savannas, coupled with their isolated location in central Amazonia relative to other larger savanna areas within the borders of the Amazon region, such as Amapá (Silva et al., 1997), Roraima-Rupununi (Robbins et al., 2004; Santos \& Silva, 2007) and the upper Marmelos River (Aleixo \& Poletto, 2007), can also explain the absence of several other typical South American savanna species recorded in those regions. Examples are: Heliactin bilophus (Horned Sungem), Melanopareia torquata (Collared Crescentchest), Polystictus pectoralis (Bearded Tachuri), Euscarthmus rufomarginatus (Rufous-sided Pygmy-Tyrant), Xolmis cinereus (Gray Monjita), Anthus lutescens (Yellowish Pipit), Cypsnagra hirundinacea (White-rumped Tanager), Emberizoides herbicola (Wedgetailed Grass-Finch) and Sporophila bourreuil (Capped Seedeater). Alter do Chão, another central Amazonian savanna site, also presents an impoverished savanna avifauna (Sanaiotti \& Cintra, 2001). Thus, local extinction is another potential explanation for the lack of some species in Monte Alegre and other small and isolated central Amazonian savannas. These species may have colonized the region during past expansions of non-forest vegetation types into the Amazonian region (Haffer \& Prance, 2001), but may have subsequently become extinct as either the habitat became unsuitable or habitat patches too small to support effective metapopulations.

Finally, among the species considered above, it is important to stress that Tyrannus albogularis and T. savanna are represented by resident and austral migrant populations in Amazonia (Sick, 1997; Infonatura, 2009), while Guira guira, Anthus lutescens and Ammodramus humeralis can be invasive species in several deforested areas, especially pastures and farmlands (Sick, 1997; Vasconcelos et al., 2007b). Thus, these species should be treated with some caution in biogeographical analyses of savanna birds.

\section{SPECIES ACCOUNTS}

Below, we present comments on distribution, taxonomy and natural history of selected species:

\section{Colinus cristatus (Crested Bobwhite)}

The only regional record for this northern South American savanna game bird is based on two specimens (a couple) collected by O. Martins in October 1916 (MPEG $13006-$ 13007). This record was probably overlooked, since it represents a range extension for this species to the midlower left bank of the Amazon River (see maps in Carrol, 1994 and Infonatura, 2009). We failed to find the Crested Bobwhite during our fieldwork and it is possible that the species could have been extirpated from the region due to hunting pressure (see below).

\section{Buteo albicaudatus (White-tailed Hawk)}

This is an uncommon species in Amazonia, with sparse records for other savanna areas, such as Marajó Island (Henriques \& Oren, 1997), Amapá (Silva et al., 1997), Alter do Chão (Sanaiotti \& Cintra, 2001), Roraima-Rupununi (Robbins et al., 2004; Santos \& Silva, 2007), upper Marmelos River (Aleixo \& Poletto, 2007) and Sipaliwini (Mittermeier et al., 2010). In Amazonia, the species was also recorded around 'terra firme' forests in the Alta Floresta region (Zimmer et al., 1997) and on the Serra dos Caiabis, in transitional forest (Lees et al., 2008). The first record for Monte Alegre is an adult bird photographed by MFV on 16 January 1999. The bird was perched on a rock outcrop atop Serra do Ererê and took flight some minutes later. On 19 January 1999, three individuals (one in dark phase) were seen flying over the same locality.

\section{Aratinga maculata (Sulfur-breasted Parakeet)}

This species is endemic to the Guianan area of endemism (Silveira et al., 2005; Mittermeier et al., 2010; Aleixo et al.,

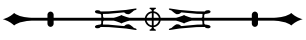


2011); records from Santarém, on the south bank of the Amazon River, are probably from captive birds or mislabeled old specimens (Silveira et al., 2005). We observed flocks of 3-8 individuals in five localities: Monte Alegre city, Campo do Desterro, Colônia do Ererê, Santana and Aruchi. Birds were observed principally in savannas but were also recorded close to forest fragments or flying over forested or urban areas. Two males that were used in the original description of $A$. pintoi (Silveira et al., 2005) were collected by JMCS, MFV and D. C. Pimentel Neto, at Colônia do Ererê on 9 January 1999 (MPEG 54330, UFPE 1792).

\section{Chordeiles pusillus (Least Nighthawk)}

In Amazonia, this species is restricted to open vegetation enclaves (savannas and 'campinas'), such as Amapá (Silva et al., 1997), Roraima-Rupununi (Robbins et al., 2004; Santos \& Silva, 2007), Jaú National Park (Borges et al., 2001; Borges, 2004), upper Marmelos River (Aleixo \& Poletto, 2007) and Sipaliwini (O'Shea, 2005; Mittermeier et al., 2010). In the early morning (05:30 h) of 11 January 1999, several individuals of $C$. pusillus were detected at Campo do Desterro by their typical song (see Cleere \& Nurney, 1998). At 07:30 h, four specimens (three males and one female) were collected by JMCS, MFV and D. C. Pimentel Neto (MPEG 54339-54341, UFPE 1780). These birds were shot when roosting on a gravel patch of c. $40 \mathrm{~m}^{2}$ amidst the savanna vegetation. Another three birds (not collected) were roosting in the same area. At dawn on 14 January 1999, five individuals were observed and heard at Colônia do Ererê. Based on plumage, these specimens were identified as C. p. septentrionalis. However, C. p. esmeraldae is the subspecies that probably moves to central and eastern Amazonia during migratory movements (Cleere \& Nurney, 1998; Cleere, 1999). Recently, Mittermeier et al. (2010) found intermixed characters of plumage and measurements of four subspecies (C. $p$. septentrionalis, C. p. esmeraldae, C. p. novaesi and C. p. pusillus) when analyzing 12 specimens from Sipaliwini. Thus, as pointed out by others (Robbins et al., 2004; Aleixo \&
Poletto, 2007; Mittermeier et al., 2010), more studies are needed to understand the taxonomy, geographical variation and migratory patterns of this species in Amazonia. It is possible that some populations are resident and that one or more subspecies are invalid due to the great individual variation that occurs in several nightjar species (Cleere \& Nurney, 1998; Cleere, 1999, 2010).

\section{Lophornis ornatus (Tufted Coquette)}

This species is known from Monte Alegre from a single male specimen (MPEG 4759) collected by E. Snethlage on 15 February 1906. This appears to be the only specimen from the mid-lower reaches of the north bank of the Amazon River (see maps in Züchner, 1999 and Infonatura, 2009).

\section{Notharchus ordii (Brown-banded Puffbird)}

This poorly known puffbird is known from scattered records in the basins of the Amazon and Orinoco (Zimmer \& Hilty, 1997; Zimmer et al., 1997; Borges et al., 2001; Rasmussen \& Collar, 2002; Infonatura, 2009). The only record for the left bank of the mid-lower Amazon River appears to be a female (MPEG 4405) collected by A. Costa on 17 November 1905.

\section{Formicivora rufa (Rusty-backed Antwren)}

Silva et al. (1997) suspected that the subspecies of the Rusty-backed Antwren occurring in Monte Alegre would be F. r. chapmani, a taxon restricted to the Amazonian savannas other than Humaitá and the upper Marmelos River (both in Amazonas state and close to the border of the 'cerrado'), where the nominate race has been collected (Silva et al., 1997; A. Aleixo \& F. Lima, personal communication). This species is known in Monte Alegre from a female (MPEG 4744) and a male (MPEG 6004), collected by E. Snethlage and O. Martins, on 14 February 1906 and on 21 July 1908, respectively. Between 10 and 19 January 1999, four specimens (one male and three females) were obtained in the Monte Alegre savannas

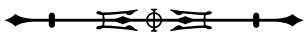


by JMCS, MFV and D. C. Pimentel Neto (MPEG 5436754370). The female specimens present heavy streaking on underparts (especially on throat) and blackish tails, typical features of F. r. chapmani, following Zimmer \& Isler (2003) (but see Pinto, 1940, 1947 for a critical point of view, suggesting that some of these characters may be related to individual variation).

\section{Suiriri suiriri (Suiriri Flycatcher)}

Suiriri Flycatcher is known from few sites in Amazonia (Silva et al., 1997; Sanaiotti \& Cintra, 2001; Robbins, 2004; Infonatura, 2009; Mittermeier et al., 2010). However, S. s. affinis is fairly common in the Monte Alegre savannas, where five specimens were collected by E. Snethlage (MPEG 5934) and by JMCS, MFV and D. C. Pimentel Neto (MPEG 54390-54391, UFPE 1770-1771).

\section{Conopias trivirgatus (Three-striped Flycatcher)}

The only nesting record for this species is based on observations of a pair of the nominate form (in Argentina) taking leaves to an old woodpecker hole in a broken branch (Narosky \& Salvador, 1998; Mobley, 2004c). The Amazonian subspecies (C. t. berlepschi) possibly represents a full species (Pinto, 1936; Ridgely \& Tudor, 1994; Mobley, 2004c), and virtually nothing is known about its breeding ecology. On 20 January 1999, JMCS and MFV observed one individual taking material to a nest located in the top of a broken branch of a dead savanna tree, c. $3 \mathrm{~m}$ above the ground (Figure 3A). The cup-shaped nest was $c$. $25 \mathrm{~cm}$ inside a hollow in this branch without any upper protection (Figure 3B). It was composed of leaves of grass, tree bark and some feathers, lined with rachis and central veins of dry dicotyledon leaves. Nest measurements (in $\mathrm{cm}$ ) were: external diameter 4.7, internal diameter 3.3 and depth 3.0. This nest was collected and deposited in the MPEG nest collection. Nesting in holes or tree cavities was also reported for other species of Conopias (Ridgely \& Tudor, 1994; Mobley, 2004a, 2004b). It has also been reported that Conopias flycatchers usurp hanging nests of caciques (Cacicus spp.) and oropendolas (Psarocolius spp.) (Ridgely \& Tudor, 1994; Sick, 1997; Mobley, 2004a, 2004b, 2004d). Close to the nest (c. $100 \mathrm{~m}$ ), there was an active colony (seven nests) of Psarocolius decumanus (Crested Oropendola), but we did not observe any Three-striped Flycatchers engaged in nesting activities there.

\section{Sicalis citrina (Stripe-tailed Yellow-Finch)}

The Stripe-tailed Yellow-Finch is a species with two main populations in South America: one north of Amazonia and the other south of this region (the North-South disjunction pattern of distribution proposed by Silva, 1995). This species has only been previously found on the borders of Amazonia (Ridgely \& Tudor, 1989; Infonatura, 2009). The first record of this species in a central Amazonian savanna is of a male (MPEG 54434), collected by JMCS, MFV and D. C. Pimentel Neto, at Serra do Ererê on 16 January 1999. This bird was associated with a flock of several other individuals that were vocalizing and performing aerial displays, similar to those described from populations south of the Amazon (Vasconcelos et al., 2007a). Small flocks of 2-5 birds were observed foraging on the ground, among clumps of grasses. Silva (1995) suggested that populations of this species might be able to disperse across Amazonia, since it has a tendency toward long-distance movements (Ridgely \& Tudor, 1989; Sick, 1997).

\section{CONSERVATION}

Vegetation types in Monte Alegre have been severely degraded by human activities since the first colonizers arrived in the region, during the $17^{\text {th }}$ century (Pastana, 1999). Savannas provided a good opportunity for cattle ranching (Pastana, 1999), probably because this open physiognomy (with native grasses) facilitated this activity, and it is possible that non-natural fires have occurred in this open vegetation type at least since the $18^{\text {th }}$ century. To what extent fires caused faunal and floral impoverishment is unknown and it is possible that even the earliest naturalists that explored the region already found degraded savanna 


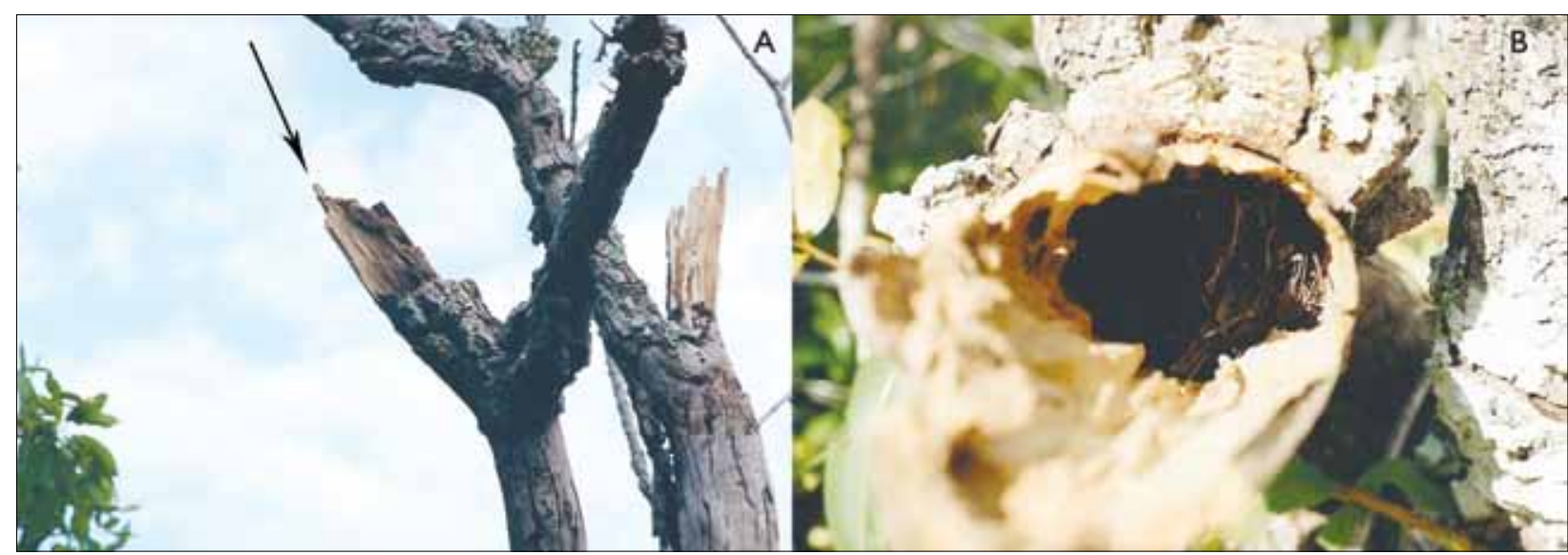

Figure 3. Nest of the Three-striped Flycatcher (Conopias trivirgatus berlepschi). A: nest entrance in the top of a broken branch, c. $3 \mathrm{~m}$ above the ground (indicated by an arrow). B: cup-shaped nest inside the branch (external diameter: $4.7 \mathrm{~cm}$ ). Photos: M. F. Vasconcelos, 1999.

vegetation in Monte Alegre. Fires continue to be set in the savannas, and the herb layer is extremely depauperate and sparsely vegetated in recently burnt areas.

Intensive logging in Monte Alegre started toward the end of the $18^{\text {th }}$ century when the Royal Sawmill ("Serraria Real") exploited the timber for commercial purposes (Pastana, 1999). This logging activity and the cocoa plantation that followed during the first years of the $19^{\text {th }}$ century were probably two early regional drivers of deforestation (Pastana, 1999). Logging activities continue in the region today, and the remnant fragments of forest are isolated and impoverished. It is possible that several forest bird species have disappeared from Monte Alegre; for example, a number of woodcreepers and antbirds of the Guianan area of endemism have not been observed despite our intense inventory (Appendix, see Cracraft, 1985; Cohn-Haft et al., 1997; Aleixo et al., 2011).

During our fieldwork, it was quite common to find traps and see people walking with shotguns, and we suspect that hunting and trapping activities are other strong human pressures on the native avifauna. For example, the only regional record for the Crested Bobwhite is based on two old specimens (see above). Furthermore, other researchers recently found several individuals of the Guianan endemic and threatened Sulfur- breasted Parakeet in captivity (A. C. Lees, N. Moura \& B. J. W. Davis, personal communication).

An important area for bird conservation was recently identified in the 'várzeas' of Monte Alegre and adjacent regions, especially because it shelters restricted-range species such as Myrmotherula klagesi (Klages' Antwren) and Cranioleuca muelleri (Scaled Spinetail) (De Luca et al., 2009).

Fortunately, the Monte Alegre State Park was decreed in November 2001. This important 5,800 ha reserve protects significant tracts of savannas and forests (Pereira et al., 2003; Garcia et al., unpublished data 2008), and will hopefully protect the regional biodiversity in this unique area of Amazonia.

\section{CONCLUSIONS}

Although the avifaunal community of the Monte Alegre savannas is typical of other savanna habitats, we failed to record several open-country birds that occur in larger savanna areas located on the borders of Amazonia such as along the Atlantic coast or close to the 'cerrado' boundaries (southern Amazonian savannas). The isolated position and small area of the Monte Alegre savannas could explain their impoverished aspect in comparison to other, larger Amazonian savannas. Nevertheless, Monte Alegre savannas shelter the Guianan endemic Sulfur-breasted Parakeet, a vulnerable species in

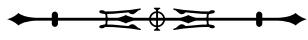


Pará state (SECTAM, 2006). Furthermore, the high regional species richness associated with the mosaic of different vegetation types makes Monte Alegre a key area for avifaunal conservation in Brazilian Amazonia.

\section{ACKNOWLEDGEMENTS}

We are especially grateful to MPEG and Secretaria do Meio Ambiente (SEMA-PA) for the logistical and financial support of our fieldwork. We also thank D. C. Pimentel Neto and J. N. Santa Brígida for their invaluable help in collecting and preparing specimens. G. Pereira (UFPE), A. Aleixo and F. Lima (MPEG) helped to obtain data from specimens deposited in those institutions. M. Maldonado-Coelho, M. S. Hoogmoed, M. Votaw and two anonymous reviewers revised early versions of the manuscript. D. Hoffmann kindly prepared Figure 1. K. -L. Schuchmann, L. F. Silveira, D. Serripieri, G. N. Maurício, V. T. Lombardi and A. Aleixo provided important bibliography. This paper is dedicated to the memory of J. Haffer for his important contributions to the biogeographical knowledge on the Amazonian avifauna.

\section{REFERENCES}

AB'SABER, A. N., 2002. Bases para o estudo dos ecossistemas da Amazônia brasileira. Estudos Avançados 16(45): 7-30.

ALEIXO, A. \& F. POLETTO, 2007. Birds of an open vegetation enclave in southern Brazilian Amazonia. The Wilson Journal of Ornithology 119(4): 610-630.

ALEIXO, A., F. POLETTO, M. F. C. LIMA, M. CASTRO, E. PORTES \& L. S. MIRANDA, 2011. Notes on the vertebrates of northern Pará, Brazil: a forgotten part of the Guianan Region, II. Avifauna. Boletim do Museu Paraense Emílio Goeldi. Ciências Naturais 6(1): 11-65.

ANDRADE-LIMA, D., 1958. Viagem aos campos de Monte Alegre, Pará. Contribuição para o conhecimento de sua flora: 1-162. Instituto Agronômico do Norte (Boletim Técnico, 36), Rio Branco.

AYOADE, J. O., 1998. Introdução à climatologia para os trópicos: 1-332. Bertrand Brasil, Rio de Janeiro.

BALCHIN, C., 2006. A potpourri of recently described species from the Neotropics. Neotropical Birding 1: 24-37.

BATES, J. M., J. G. TELLO \& J. M. C. SILVA, 2003. Initial assessment of genetic diversity in ten bird species of South American Cerrado. Studies on Neotropical Fauna and Environment 38(2): 87-94.
BIRDLIFE INTERNATIONAL, 2009. Search for species. Available in: <http://www.birdlife.org/datazone/species/index.html>. Accessed on: 22 December 2009.

BONACCORSO, E., I. KOCH \& A. T. PETERSON, 2006. Pleistocene fragmentation of Amazon species' ranges. Diversity and Distributions 12(2): 157-164.

BORGES, S. H., 2004. Species poor but distinct: bird assemblages in white sand vegetation in Jaú National Park, Brazilian Amazon. Ibis 146(1): 114-124.

BORGES, S. H., M. COHN-HAFT, A. M. P. CARVALHAES, L. M. HENRIQUES, J. F. PACHECO \& A. WHITTAKER, 2001. Birds of Jaú National Park, Brazilian Amazon: species check-list, biogeography and conservation. Ornitología Neotropical 12(2): 109-140.

BUSH, M. B. \& P. E. OLIVEIRA, 2006. The rise and fall of the refugial hypothesis of Amazonian speciation: a paleoecological perspective. Biota Neotropica 6(1): 1-17.

CARROL, J. P., 1994. Family Odontophoridae (new world quails). In: J. DEL HOYO, A. ELLIOTT \& J. SARGATAL (Eds.): Handbook of the birds of the world. V. 2: 412-433. Lynx Edicions, Barcelona.

CLEERE, N., 1999. Family Caprimulgidae (nightjars). In: J. DEL HOYO, A. ELLIOTT \& J. SARGATAL (Eds.): Handbook of the birds of the world. v. 5: 302-386. Lynx Edicions, Barcelona.

CLEERE, N., 2010. Nightjars of the world: 1-464. Wild Guides, Hampshire.

CLEERE, N. \& D. NURNEY, 1998. Nightjars: a guide to the nightjars, nighthawks and their relatives: 1-317. Yale University Press, New Haven \& London.

COHN-HAFT, M., A. WHITTAKER \& P. C. STOUFFER, 1997. A new look at the "species-poor" central Amazon: the avifauna north of Manaus, Brazil. Ornithological Monographs 48: 205-235.

COMITÊ BRASILEIRO DE REGISTROS ORNITOLÓGICOS (CBRO), 2009. Lista das aves do Brasil - 8. ed. Available at: <http://www.cbro.org.br/CBRO/listabr.htm>. Accessed on: 5 September 2009.

CRACRAFT, J., 1985. Historical biogeography and patterns of differentiation within the South American avifauna: areas of endemism. Ornithological Monographs 36: 49-84.

DE LUCA, A. C., P. F. DEVELEY, G. A. BENCKE \& J. M. GOERCK, 2009. Áreas importantes para a conservação das aves no Brasil: parte II - Amazônia, Cerrado e Pantanal: 1-361. SAVE Brasil, São Paulo.

GOTTSBERGER, G. \& I. SILBERBAUER-GOTTSBERGER, 2006. Life in the Cerrado - a South American tropical seasonal ecosystem: v. 1: 1-277. Reta Verlag, Ulm. 
HAFFER, J., 1967. Zoogeographical notes on the "nonforest" lowland bird faunas of northwestern South America. El Hornero 10(4): 315-333.

HAFFER, J., 1969. Speciation in Amazonian forest birds. Science 165(3889): 131-137.

HAFFER, J., 1974. Avian speciation in tropical South America, with a systematic survey of the toucans (Ramphastidae) and jacamars (Galbulidae). Publications of the Nuttall Ornithological Club 14: 1-390.

HAFFER, J., 1985. Avian zoogeography of the Neotropical lowlands. Ornithological Monographs 36: 113-145.

HAFFER, J., 1987. Biogeography of Neotropical birds. In: T. C. WHITMORE \& G. T. PRANCE (Eds.): Biogeography and Quaternary history in tropical America: 105-150. Clarendon Press, Oxford.

HAFFER, J. \& G. T. PRANCE, 2001. Climatic forcing of evolution in Amazonia during the Cenozoic: on the refuge theory of biotic differentiation. Amazoniana 16(3/4): 579-607.

HENRIQUES, L. M. P. \& D. C. OREN, 1997. The avifauna of Marajó, Caviana and Mexiana islands, Amazon River estuary, Brazil. Revista Brasileira de Biologia 57(3): 357-382.

INFONATURA, 2009. Animais e ecossistemas da América Latina. Available in: <http://www.natureserve.org/infonatura/>. Accessed on: 29 November 2009.

LEES, A. C., B. J. W. DAVIS, A. V. G. OLIVEIRA \& C. A. PERES, 2008. Avifauna of a structurally heterogeneous forest landscape in the Serra dos Caiabis, Mato Grosso, Brazil: a preliminary assessment. Cotinga 29: 149-159.

MACHADO, A. B. M., C. S. MARTINS \& G. M. DRUMMOND, 2005. Lista da fauna brasileira ameaçada de extinção: incluindo as listas de espécies quase ameaçadas e deficientes em dados: 1-157. Fundação Biodiversitas, Belo Horizonte.

MAGNUSSON, W. E., A. P. LIMA, A. L. K. M. ALBERNAZ, T. M. SANAIOTTI \& J. L. GUILLAUMET, 2008. Composição florística e cobertura vegetal das savanas na região de Alter do Chão, Santarém - PA. Revista Brasileira de Botânica 31(1): 165-177.

MIRANDA, I. S., 1993. Estrutura do estrato arbóreo do cerrado amazônico em Alter-do-Chão, Pará, Brasil. Revista Brasileira de Botânica 16(2): 143-150.

MIRANDA, I. S. \& M. L. ABSY, 2000. Fisionomia das savanas de Roraima, Brasil. Acta Amazonica 30(3): 423-440.

MIRANDA-RIBEIRO, A., 1938. Notas ornithologicas (XIII) Tinamidae (inhambús, jaós, taós, macucos, codornas, "perdizes", etc.). Revista do Museu Paulista 23: 667-788.
MITTERMEIER, J. C., K. ZYSKOWSKI, E. S. STOWE \& J. E. LAI, 2010. Avifauna of the Sipaliwini savanna (Suriname) with insights into its biogeographic affinities. Bulletin of the Peabody Museum of Natural History 51(1): 97-122.

MOBLEY, J. A., 2004a. White-ringed Flycatcher Conopias albovittatus. In: J. DEL HOYO, A. ELLIOTT \& D. A. CHRISTIE (Eds.): Handbook of the birds of the world. v. 9: 411. Lynx Edicions, Barcelona.

MOBLEY, J. A., 2004b. Yellow-throated Flycatcher Conopias parvus. In: J. DEL HOYO, A. ELLIOTT \& D. A. CHRISTIE (Eds.): Handbook of the birds of the world. v. 9: 411. Lynx Edicions, Barcelona.

MOBLEY, J. A., 2004c. Three-striped Flycatcher Conopias trivirgatus. In: J. DEL HOYO, A. ELLIOTT \& D. A. CHRISTIE (Eds.): Handbook of the birds of the world. v. 9: 411-412. Lynx Edicions, Barcelona.

MOBLEY, J. A., 2004d. Lemon-browed Flycatcher Conopias cinchoneti. In: J. DEL HOYO, A. ELLIOTT \& D. A. CHRISTIE (Eds.): Handbook of the birds of the world. v. 9: 412. Lynx Edicions, Barcelona.

MORAES, B. G., J. M. N. COSTA, A. C. L. COSTA \& M. H. COSTA, 2005. Variação espacial e temporal da precipitação no estado do Pará. Acta Amazonica 35(2): 207-214.

NAKA, L. N., M. COHN-HAFT, F. MALLET-RODRIGUES, M. P. D. SANTOS \& M. F. TORRES, 2006. The avifauna of the Brazilian state of Roraima: bird distribution and biogeography in the Rio Branco basin. Revista Brasileira de Ornitologia 14(3): 197-238

NAROSKY, T. \& S. SALVADOR, 1998. Nidificación de las aves argentinas (Tyrannidae): 1-135. Asociación Ornitológica del Plata, Buenos Aires.

NEMÉSIO, A. \& C. RASMUSSEN, 2009. The rediscovery of Buffon's "Guarouba" or "Perriche jaune": two senior synonyms of Aratinga pintoi Silveira, Lima \& Höfling, 2005 (Aves: Psittaciformes). Zootaxa 2013: 1-16.

OLIVEIRA-JÚNIOR, R. C., T. E. RODRIGUES, P. L. SANTOS \& M. A. VALENTE, 1999. Zoneamento agroecológico do município de Monte Alegre, estado do Pará: 1-87. Embrapa Amazônia Oriental, Belém.

O'SHEA, B. J., 2005. Notes on birds of the Sipaliwini savanna and other localities in southern Suriname, with six new species for the country. Ornitología Neotropical 16(3): 361-370.

PASTANA, J. M. N., 1999. Diagnóstico do potencial ecoturístico do município de Monte Alegre: 1-88. Companhia de Pesquisa de Recursos Minerais, Belém. Available at: <http://www.cprm. gov.br/gestao/ecotur/diag_ecoturistico.pdf $>$. Accessed on: 29 November 2009 
PAYNTER, R. A. \& M. A. TRAYLOR, 1991. Ornithological Gazetteer of Brazil: 1-789. Museum of Comparative Zoology, Cambridge.

PENNINGTON, R. T., D. E. PRADO \& C. A. PENDRY, 2000. Neotropical seasonally dry forests and Quaternary vegetation changes. Journal of Biogeography 27(2): 261-273.

PENNINGTON, R. T., G. P. LEWIS \& J. A. RATTER, 2006. An overview of the plant diversity, biogeography and conservation of Neotropical savannas and seasonally dry forests. In: R. T. PENNINGTON, G. P. LEWIS \& J. A. RATTER (Eds.): Neotropical savannas and seasonally dry forests: plant diversity, biogeography, and conservation: 1-29. CRC Press, Boca Raton.

PEREIRA, J. L. G., M. F. F. SILVA, M. C. THALES, A. M. VALENTE \& R. OLIVEIRA, 2003. Classificação da cobertura da terra na área do entorno do Parque Estadual de Monte Alegre - PA. Anais XI Simpósio Brasileiro de Sensoriamento Remoto. Available at: <http://marte.dpi.inpe.br/col/tid.inpe.br/sbsr/2002/11.14.15.27/ doc/19_188.pdf $>$. Accessed on: 4 January 2010.

PINTO, O. M. O., 1936. Notas de Ornithologia Amazonica. Revista do Museu Paulista 20: 229-244.

PINTO, O. M. O., 1940. Nova contribuição à Ornitologia de Mato-Grosso. Arquivos de Zoologia do Estado de São Paulo 2(1): 1-38.

PINTO, O. M. O., 1944. Catalogo das aves do Brasil e lista dos exemplares existentes na coleção do Departamento de Zoologia - $2^{\mathrm{a}}$ parte Ordem Passeriformes (continuação): Superfamília Tyrannoidea e Subordem Passeres: 1-700. Secretaria da Agricultura, Indústria e Comércio, São Paulo.

PINTO, O. M. O., 1945. Cinqüenta anos de investigação ornitológica. Arquivos de Zoologia do Estado de São Paulo 4: 1-80.

PINTO, O. M. O., 1947. Contribuição à Ornitologia do baixo Amazonas. Arquivos de Zoologia do Estado de São Paulo 5(6): 311-482.

PINTO, O. M. O., 1979. A ornitologia do Brasil através das idades (século XVI a século XIX): 1-117. Brasiliensia Documenta, São Paulo.

PIRES, J. M. \& G. T. PRANCE, 1985. The vegetation types of the Brazilian Amazon. In: G. T. PRANCE \& T. E. LOVEJOY (Eds.): Key environments: Amazonia: 109-145. Pergamon Press, Oxford.

PRANCE, G. T., 1978. The origin and evolution of the Amazon flora. Interciencia 3(4): 207-222.

PRANCE, G. T., 1987. Vegetation. In: T. C. WHITMORE \& G. T. PRANCE (Eds.): Biogeography and Quaternary history in tropical America: 28-45. Clarendon Press, Oxford.
RASMUSSEN, P. C. \& N. J. COLLAR, 2002. Family Bucconidae (puffbirds). In: J. DEL HOYO, A. ELLIOTT \& J. SARGATAL (Eds.): Handbook of the birds of the world. v. 7: 102-138. Lynx Edicions, Barcelona.

RATTER, J. A., S. BRIDGEWATER \& J. F. RIBEIRO, 2006. Biodiversity patterns of the woody vegetation of the Brazilian Cerrado. In: R. T. PENNINGTON, G. P. LEWIS \& J. A. RATTER (Eds.): Neotropical savannas and seasonally dry forests: plant diversity, biogeography, and conservation: 31-66. CRC Press, Boca Raton.

RIDGELY, R. S. \& G. TUDOR, 1989. The birds of South America. v. 1: 1-516. University of Texas Press, Austin.

RIDGELY, R. S. \& G. TUDOR, 1994. The birds of South America. v. 2: 1-814. University of Texas Press, Austin.

ROBBINS, M. B., 2004. Suiriri Flycatcher Suiriri suiriri. In: J. DEL HOYO, A. ELLIOTT \& D. A. CHRISTIE (Eds.): Handbook of the birds of the world. v. 9: 276. Lynx Edicions, Barcelona.

ROBBINS, M. B., M. J. BRAUN \& D. W. FINCH, 2004. Avifauna of the Guyana southern Rupununi, with comparisons to other savannas of northern South America. Ornitología Neotropical 15(2): 173-200.

RUSCHI, A., 1951. Trochilideos do Museu Nacional. Boletim do Museu de Biologia Prof. Mello Leitão, Série Biologia 10: 1-111.

SANAIOTTI, T. M. \& R. CINTRA, 2001. Breeding and migrating birds in an Amazonian savanna. Studies on Neotropical Fauna and Environment 36(1): 23-32.

SANAIOTTI, T. M., S. BRIDGEWATER \& J. A. RATTER, 1997. A floristic study of the savanna vegetation of the state of Amapá, Brazil, and suggestions for its conservation. Boletim do Museu Paraense Emílio Goeldi, série Botânica 13(1): 3-29.

SANTOS, M. P. D. \& J. M. C. SILVA, 2007. As aves das savanas de Roraima. Revista Brasileira de Ornitologia 15(2): 189-207.

SCLATER, P. L. \& O. SALVIN, 1867. List of birds collected by Mr. Wallace on the lower Amazons and Rio Negro. Proceedings of the Zoological Society of London 1867: 566-596.

SECRETARIA DE ESTADO DE CIÊNCIA, TECNOLOGIA E MEIO AMBIENTE (SECTAM), 2006. Relação das espécies ameaçadas do estado do Pará. Available at: <www.sectam.pa.gov.br>. Accessed on: 2 September 2006.

SICK, H., 1997. Ornitologia Brasileira: 1-912. Editora Nova Fronteira, Rio de Janeiro.

SILVA, J. M. C., 1995. Biogeographic analysis of the South American Cerrado avifauna. Steenstrupia 21(1): 49-67.

SILVA, J. M. C., D. C. OREN, J. C. ROMA\& \&. M. P. HENRIQUES, 1997. Composition and distribution patterns of the avifauna of an Amazonian upland savanna, Amapá, Brazil. Ornithological Monographs 48: 743-762.

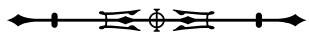


SILVA, J. M. C. \& J. M. BATES, 2002. Biogeographic patterns and conservation in the South American Cerrado: a tropical savanna hotspot. BioScience 52(3): 225-233.

SILVEIRA, L. F., 2005. A "descoberta" do cacaué (Aratinga pintoi): uma visão pessoal. Atualidades Ornitológicas 123: 14.

SILVEIRA, L. F., F. C. T. LIMA \& E. HÖFLING, 2005. A new species of Aratinga parakeet (Psittaciformes: Psittacidae) from Brazil, with taxonomic remarks on the Aratinga solstitialis complex. The Auk 122(1): 292-305.

SNETHLAGE, E., 1906. Über unteramazonische vögel. Journal für Ornithologie 54: 407-411, 519-526.

SNETHLAGE, E., 1907. Über unteramazonische vögel. Journal für Ornithologie 55: 283-299.

SNETHLAGE, E., 1909. Sobre a distribuição da avifauna campestre na Amazonia. Boletim do Museu Goeldi (Museu Paraense) de História Natural e Ethnographia 6: 226-235.

SNETHLAGE, E., 1914. Catalogo das aves amazonicas contendo todas as especies descriptas e mencionadas até 1913. Boletim do Museu Goeldi (Museu Paraense) de História Natural e Ethnographia 8: 1-530.

SNETHLAGE, H., 1930. Dr. Emilie Snethlage zum Gedächtnis. Journal für Ornithologie 78(1): 123-134.

STOTZ, D. F., J. W. FITZPATRICK, T. A. PARKER III \& D. K. MOSKOVITS, 1996. Neotropical birds: ecology and conservation: 1-502. University of Chicago Press, Chicago.

VASCONCELOS, M. F., V. T. LOMBARDI \& S. D'ANGELO NETO 2007a. Notas sobre o canário-rasteiro (Sicalis citrina) nas serras de Minas Gerais, Brasil. Atualidades Ornitológicas 140: 6-7.
VASCONCELOS, M. F., J. F. PACHECO \& R. PARRINI, $2007 \mathrm{~b}$. Levantamento e conservação da avifauna na zona urbana de Marabá, Pará, Brasil. Cotinga 28: 45-51.

VASCONCELOS, M. F. \& J. M. C. SILVA, 2005. Plantas ornitófilas e beija-flores observados na savana Amazônica da Serra do Ererê, Monte Alegre, Pará, Brasil. Atualidades Ornitológicas 128: 14-15.

VICENTINI, A., 2004. A vegetação ao longo de um gradiente edáfico no Parque Nacional do Jaú. In: S. H. BORGES, S. IWANAGA, C. C. DURIGAN \& M. R. PINHEIRO (Eds.): Janelas para a biodiversidade no Parque Nacional do Jaú: uma estratégia para o estudo da biodiversidade na Amazônia: 105-134. Fundação Vitória Amazônica, Manaus.

XENO-CANTO, 2009. Sharing bird sounds from around the world. Available at: <http://www.xeno-canto.org/>. Accessed on: 22 December 2009.

ZIMMER, K. J., T. A. PARKER III, M. L. ISLER \& P. R. ISLER, 1997. Survey of a southern Amazonia avifauna: the Alta Floresta region, Mato Grosso, Brazil. Ornithological Monographs 48: 887-918.

ZIMMER, K. J. \& S. L. HILTY, 1997. Avifauna of a locality in the upper Orinoco drainage of Amazonas, Venezuela. Ornithological Monographs 48: 865-885.

ZIMMER, K. J. \& M. L. ISLER, 2003. Family Thamnophilidae (typical antbirds). In: J. DEL HOYO, A. ELLIOTT \& D. A. CHRISTIE (Eds.): Handbook of the birds of the world. v. 8: 448-681. Lynx Edicions, Barcelona.

ZÜCHNER, T., 1999. Tufted Coquette Lophornis ornatus. In: J. DEL HOYO, A. ELLIOTT \& J. SARGATAL (Eds.): Handbook of the birds of the world. v. 5: 567. Lynx Edicions, Barcelona. 
APPENDIX. Birds recorded in the Monte Alegre region, Pará, Brazil. Evidence: $s 1=$ specimen housed in MPEG; s2 = specimen housed in UFPE; s3 = specimen housed in MZUSP; s4 = specimen housed in MNRJ; s5 = specimen housed in AMNH; s6 = specimen housed in $\mathrm{FMNH} ; \mathrm{p}=$ photograph; $\mathrm{t}=$ tape-recording; when not documented records are presented as: $\mathrm{o}=$ observation (sight record) or $v=$ record of vocalization (with or without observation). Habitat: $C=$ 'campinarana'; $F=$ flooded forest; $L=$ open waterbodies (lakes and rivers); $M=$ man-made, disturbed areas (pastures, agricultural fields, ranches and urban areas); $\mathrm{S}=$ savanna; $T$ = 'terra firme' forest; $\vee=$ 'campo de várzea'.

(Continued)

\begin{tabular}{|c|c|c|c|c|c|}
\hline Order/Family/Species & English name & Evidence & Habitat & $\begin{array}{c}\text { Previous } \\
\text { fieldworkers }\end{array}$ & $\begin{array}{l}\text { Present } \\
\text { study }\end{array}$ \\
\hline \multicolumn{6}{|l|}{ Tinamiformes } \\
\hline Tinamidae & Tinamous & & & & \\
\hline Crypturellus cinereus (Gmelin, 1789) & Cinereous Tinamou & s1 & $C, F, T$ & $x$ & \\
\hline Crypturellus soui (Hermann, 1783) & Little Tinamou & s1 & $\mathrm{C}, \mathrm{T}$ & $x$ & $x$ \\
\hline Crypturellus undulatus (Temminck, 1815) & Undulated Tinamou & $0, v$ & $C, F, T, V$ & & $x$ \\
\hline Crypturellus erythropus (Pelzeln, 1863) & Red-legged Tinamou & s1 & $C, T$ & $x$ & \\
\hline \multicolumn{6}{|l|}{ Anseriformes } \\
\hline Anhimidae & Screamers & & & & \\
\hline Anhima cornuta (Linnaeus, 1766) & Horned Screamer & O & $L$ & & $x$ \\
\hline Anatidae & Ducks & & & & \\
\hline Dendrocygna autumnalis (Linnaeus, 1758) & Black-bellied Whistling-Duck & O & L & & $x$ \\
\hline Cairina moschata (Linnaeus, 1758) & Muscovy Duck & o & L & & $x$ \\
\hline Amazonetta brasiliensis (Gmelin, 1789) & Brazilian Teal & $p$ & L & & $x$ \\
\hline \multicolumn{6}{|l|}{ Galliformes } \\
\hline Cracidae & Guans and Currassows & & & & \\
\hline Ortalis motmot (Linnaeus, 1766) & Little Chachalaca & s1 & C, F, S, T & $x$ & $x$ \\
\hline Aburria cumanensis (Jacquin, 1784) & Blue-throated Piping Guan & s1 & $\mathrm{F}, \mathrm{T}$ & $x$ & \\
\hline Odontophoridae & New World Quails & & & & \\
\hline Colinus cristatus (Linnaeus, 1766) & Crested Bobwhite & s1 & S & $x$ & \\
\hline \multicolumn{6}{|l|}{ Podicipediformes } \\
\hline Podicipedidae & Grebes & & & & \\
\hline Tachybaptus dominicus (Linnaeus, 1766) & Least Grebe & s1 & L & $x$ & \\
\hline \multicolumn{6}{|l|}{ Pelecaniformes } \\
\hline Phalacrocoracidae & Cormorants & & & & \\
\hline Phalacrocorax brasilianus (Gmelin, 1789) & Neotropic Cormorant & ○ & $\mathrm{L}$ & & $x$ \\
\hline \multicolumn{6}{|l|}{ Ciconiiformes } \\
\hline Ardeidae & Herons & & & & \\
\hline Tigrisoma lineatum (Boddaert, 1783) & Rufescent Tiger-Heron & s1 & $\mathrm{L}$ & $x$ & $x$ \\
\hline Agamia agami (Gmelin, 1789) & Agami Heron & s1 & $\mathrm{L}$ & $x$ & \\
\hline Ixobrychus exilis (Gmelin, 1789) & Least Bittern & s1 & $\mathrm{L}$ & $x$ & \\
\hline Nycticorax nycticorax (Linnaeus, 1758) & Black-crowned Night-Heron & O & L & & $x$ \\
\hline Butorides striata (Linnaeus, 1758) & Striated Heron & s1 & L & $x$ & $x$ \\
\hline
\end{tabular}


(Continued)

\begin{tabular}{|c|c|c|c|c|c|}
\hline Order/Family/Species & English name & Evidence & Habitat & $\begin{array}{c}\text { Previous } \\
\text { fieldworkers }\end{array}$ & $\begin{array}{l}\text { Present } \\
\text { study }\end{array}$ \\
\hline Bubulcus ibis (Linnaeus, 1758) & Cattle Egret & $\circ$ & $L, M$ & & $x$ \\
\hline Ardea cocoi Linnaeus, 1766 & Cocoi Heron & $\circ$ & $\mathrm{L}$ & & $x$ \\
\hline Ardea alba Linnaeus, 1758 & Great Egret & $\circ$ & $\mathrm{L}$ & & $x$ \\
\hline Pilherodius pileatus (Boddaert, 1783) & Capped Heron & s1 & $\mathrm{L}$ & $x$ & \\
\hline Egretta thula (Molina, 1782) & Snowy Egret & $\circ$ & $\mathrm{L}$ & & $x$ \\
\hline Threskiornithidae & Ibises and Spoonbills & & & & \\
\hline $\begin{array}{l}\text { Mesembrinibis cayennensis } \\
\text { (Gmelin, 1789) }\end{array}$ & Green Ibis & $\circ$ & $\mathrm{F}, \mathrm{L}$ & & $x$ \\
\hline Theristicus caudatus (Boddaert, 1783) & Buff-necked Ibis & $\mathrm{o}, \mathrm{v}$ & $\mathrm{S}, \mathrm{V}$ & & $x$ \\
\hline \multicolumn{6}{|l|}{ Cathartiformes } \\
\hline Cathartidae & Vultures & & & & \\
\hline Cathartes aura (Linnaeus, 1758) & Turkey Vulture & $\circ$ & $\begin{array}{c}C, F, L, M, S, \\
T, V\end{array}$ & & $x$ \\
\hline Cathartes burrovianus Cassin, 1845 & Lesser Yellow-headed Vulture & $\circ$ & $\mathrm{S}, \mathrm{V}$ & & $x$ \\
\hline Coragyps atratus (Bechstein, 1793) & Black Vulture & $\circ$ & $\begin{array}{c}\text { C, F, L, M, S, } \\
T, V\end{array}$ & & $x$ \\
\hline \multicolumn{6}{|l|}{ Falconiformes } \\
\hline Accipitridae & Hawks and Eagles & & & & \\
\hline Gampsonyx swainsonii Vigors, 1825 & Pearl Kite & $s 1, s 2$ & $\mathrm{~S}$ & $x$ & $x$ \\
\hline Rostrhamus sociabilis (Vieillot, 1817) & Snail Kite & $\circ$ & $\mathrm{L}$ & & $x$ \\
\hline Buteogallus urubitinga (Gmelin, 1788) & Great Black-Hawk & $\circ$ & $\mathrm{F}, \mathrm{S}, \mathrm{T}, \mathrm{V}$ & & $x$ \\
\hline Busarellus nigricollis (Latham, 1790) & Black-collared Hawk & ○ & $F, L, V$ & & $x$ \\
\hline Rupornis magnirostris (Gmelin, 1788) & Roadside Hawk & s1 & $\begin{array}{c}\mathrm{C}, \mathrm{F}, \mathrm{L}, \mathrm{M}, \mathrm{S}, \\
\mathrm{T}, \mathrm{V}\end{array}$ & $x$ & $x$ \\
\hline Buteo albicaudatus Vieillot, 1816 & White-tailed Hawk & $\mathrm{p}$ & $\mathrm{S}$ & & $x$ \\
\hline Buteo nitidus (Latham, 1790) & Gray Hawk & $\circ$ & $F, M, S, V$ & & $x$ \\
\hline Spizaetus tyrannus (Wied, 1820) & Black Hawk-Eagle & $\circ$ & $\mathrm{F}, \mathrm{T}$ & & $x$ \\
\hline Falconidae & Falcons and Caracaras & & & & \\
\hline Daptrius ater Vieillot, 1816 & Black Caracara & s1 & $\mathrm{C}, \mathrm{F}, \mathrm{T}$ & $x$ & \\
\hline $\begin{array}{l}\text { Caracara plancus } \\
\text { (Miller, 1777) }\end{array}$ & Southern Caracara & $\circ$ & $\begin{array}{c}\mathrm{C}, \mathrm{F}, \mathrm{L}, \mathrm{M}, \mathrm{S}, \mathrm{T} \\
\mathrm{T}, \mathrm{V}\end{array}$ & & $x$ \\
\hline $\begin{array}{l}\text { Milvago chimachima } \\
\text { (Vieillot, 1816) }\end{array}$ & Yellow-headed Caracara & s2 & $\begin{array}{c}\mathrm{C}, \mathrm{F}, \mathrm{L}, \mathrm{M}, \mathrm{S}, \\
\mathrm{T}, \mathrm{V}\end{array}$ & & $x$ \\
\hline $\begin{array}{l}\text { Herpetotheres cachinnans } \\
\text { (Linnaeus, 1758) }\end{array}$ & Laughing Falcon & $0, v$ & $C, M, S, T, V$ & & $x$ \\
\hline Micrastur semitorquatus (Vieillot, 1817) & Collared Forest-Falcon & s1 & $\mathrm{F}, \mathrm{T}$ & $x$ & $x$ \\
\hline
\end{tabular}


(Continued)

\begin{tabular}{|c|c|c|c|c|c|}
\hline Order/Family/Species & English name & Evidence & Habitat & $\begin{array}{c}\text { Previous } \\
\text { fieldworkers }\end{array}$ & $\begin{array}{l}\text { Present } \\
\text { study }\end{array}$ \\
\hline Falco rufigularis Daudin, 1800 & Bat Falcon & o & $C, F, S, T$ & & $x$ \\
\hline \multicolumn{6}{|l|}{ Gruiformes } \\
\hline Aramidae & Limpkins & & & & \\
\hline Aramus guarauna (Linnaeus, 1766) & Limpkin & $p$ & $\mathrm{~L}$ & & $x$ \\
\hline Rallidae & Rails & & & & \\
\hline Aramides cajanea (Statius Muller, 1776) & Gray-necked Wood-Rail & s2 & $F, L, V$ & & $x$ \\
\hline Porphyrio flavirostris (Gmelin, 1789) & Azure Gallinule & s1 & $\mathrm{L}$ & $x$ & \\
\hline Heliornithidae & Finfoots & & & & \\
\hline Heliornis fulica (Boddaert, 1783) & Sungrebe & $\mathrm{s} 1, \mathrm{t}$ & L & $x$ & $x$ \\
\hline Eurypygidae & Sunbitterns & & & & \\
\hline Eurypyga helias (Pallas, 1781) & Sunbittern & s1 & $F, L, V$ & $x$ & $x$ \\
\hline \multicolumn{6}{|l|}{ Charadriiformes } \\
\hline Charadriidae & Plovers & & & & \\
\hline Vanellus chilensis (Molina, 1782) & Southern Lapwing & $0, v$ & $L, M, S, V$ & & $x$ \\
\hline Recurvirostridae & Stilts & & & & \\
\hline $\begin{array}{l}\text { Himantopus mexicanus } \\
\text { (Statius Muller, 1776) }\end{array}$ & Black-necked Stilt & s1 & $L, V$ & $x$ & \\
\hline Scolopacidae & Sandpipers & & & & \\
\hline Gallinago paraguaiae (Vieillot, 1816) & South American Snipe & s1 & $L, V$ & $x$ & \\
\hline Actitis macularius (Linnaeus, 1766) & Spotted Sandpiper & $\circ$ & L & & $x$ \\
\hline Tringa solitaria Wilson, 1813 & Solitary Sandpiper & s1 & L & $x$ & $x$ \\
\hline Jacanidae & Jacanas & & & & \\
\hline Jacana jacana (Linnaeus, 1766) & Wattled Jacana & $0, v$ & L, V & & $x$ \\
\hline Sternidae & Terns & & & & \\
\hline Phaetusa simplex (Gmelin, 1789) & Large-billed Tern & s1 & $\mathrm{L}$ & $x$ & $x$ \\
\hline \multicolumn{6}{|l|}{ Columbiformes } \\
\hline Columbidae & Pigeons and Doves & & & & \\
\hline Columbina passerina (Linnaeus, 1758) & Common Ground-Dove & s1, s2 & $M, S, V$ & $x$ & $x$ \\
\hline Columbina minuta (Linnaeus, 1766) & $\begin{array}{l}\text { Plain-breasted } \\
\text { Ground-Dove }\end{array}$ & $s 1, s 2$ & $M, S$ & & $x$ \\
\hline Columbina talpacoti (Temminck, 1811) & Ruddy Ground-Dove & s1 & $M, S$ & $x$ & \\
\hline Claravis pretiosa (Ferrari-Perez, 1886) & Blue Ground-Dove & $\mathrm{o}, \mathrm{v}$ & $C, S, T$ & & $x$ \\
\hline Columba livia Gmelin, 1789 & Rock Dove & $\circ$ & M & & $x$ \\
\hline Patagioenas speciosa (Gmelin, 1789) & Scaled Pigeon & s1 & C, F, T & $x$ & $x$ \\
\hline $\begin{array}{l}\text { Patagioenas cayennensis } \\
\text { (Bonnaterre, 1792) }\end{array}$ & Pale-vented Pigeon & ○ & $\begin{array}{c}C, F, M, S, \\
T, V\end{array}$ & & $x$ \\
\hline
\end{tabular}


(Continued)

\begin{tabular}{|c|c|c|c|c|c|}
\hline Order/Family/Species & English name & Evidence & Habitat & $\begin{array}{c}\text { Previous } \\
\text { fieldworkers }\end{array}$ & $\begin{array}{l}\text { Present } \\
\text { study }\end{array}$ \\
\hline Zenaida auriculata (Des Murs, 1847) & Eared Dove & s1, s2 & $\begin{array}{l}C, F, M, S \\
T, V\end{array}$ & $x$ & $x$ \\
\hline Leptotila verreauxi Bonaparte, 1855 & White-tipped Dove & s1 & $\begin{array}{l}C, F, M, S \\
T, V\end{array}$ & $x$ & $x$ \\
\hline $\begin{array}{l}\text { Leptotila rufaxilla } \\
\text { (Richard \& Bernard, 1792) }\end{array}$ & Gray-fronted Dove & s2 & $\mathrm{F}, \mathrm{T}$ & & $x$ \\
\hline Geotrygon montana (Linnaeus, 1758) & Ruddy Quail-Dove & o & $C, T$ & & $x$ \\
\hline \multicolumn{6}{|l|}{ Psittaciformes } \\
\hline Psittacidae & Parrots & & & & \\
\hline $\begin{array}{l}\text { Anodorhynchus hyacinthinus } \\
\text { (Latham, 1790) }\end{array}$ & Hyacinth Macaw & s1 & $\mathrm{T}, \mathrm{V}$ & $x$ & \\
\hline Ara macao (Linnaeus, 1758) & Scarlet Macaw & o & $F, T, V$ & & $x$ \\
\hline Orthopsittaca manilata (Boddaert, 1783) & Red-bellied Macaw & s1 & $\mathrm{C}, \mathrm{T}, \mathrm{V}$ & $x$ & $x$ \\
\hline Primolius maracana (Vieillot, 1816) & Blue-winged Macaw & $\mathrm{p}, \mathrm{t}$ & $\vee$ & & $x$ \\
\hline Aratinga maculata (Statius Muller, 1776) & Sulfur-breasted Parakeet & $\begin{array}{c}\text { s1, s2, s3, s4 } \\
\text { s5, s6, p, t }\end{array}$ & S & $x$ & $x$ \\
\hline Aratinga aurea (Gmelin, 1788) & Peach-fronted Parakeet & $s 1, s 2, t$ & C, S & $x$ & $x$ \\
\hline Pyrrhura amazonum Hellmayr, 1906 & Hellmayr's Parakeet & s1 & $\mathrm{T}$ & $x$ & \\
\hline Forpus passerinus (Linnaeus, 1758) & Green-rumped Parrotlet & s1, s2 & $C, S$ & $x$ & $x$ \\
\hline $\begin{array}{l}\text { Brotogeris versicolurus } \\
\text { (Statius Muller, 1776) }\end{array}$ & Canary-winged Parakeet & $0, v$ & $S, V$ & & $x$ \\
\hline Brotogeris chrysoptera (Linnaeus, 1766) & Golden-winged Parakeet & s1 & $C, F, T$ & $x$ & \\
\hline $\begin{array}{l}\text { Brotogeris sanctithomae } \\
\text { (Statius Muller, 1776) }\end{array}$ & Tui Parakeet & s1 & $\mathrm{F}, \mathrm{T}$ & $x$ & \\
\hline Graydidascalus brachyurus (Kuhl, 1820) & Short-tailed Parrot & s1 & $\mathrm{F}$ & $x$ & \\
\hline Pionus menstruus (Linnaeus, 1766) & Blue-headed Parrot & $0, v$ & $\mathrm{~F}, \mathrm{~T}$ & & $x$ \\
\hline Amazona festiva (Linnaeus, 1758) & Festive Parrot & s1 & $F, V$ & $x$ & \\
\hline Amazona amazonica (Linnaeus, 1766) & Orange-winged Parrot & $\mathrm{t}$ & $\mathrm{C}, \mathrm{F}, \mathrm{T}, \mathrm{V}$ & & $x$ \\
\hline \multicolumn{6}{|l|}{ Cuculiformes } \\
\hline Cuculidae & Cuckoos & & & & \\
\hline Coccycua minuta (Vieillot, 1817) & Little Cuckoo & $s 1, s 2, t$ & $\mathrm{C}, \mathrm{F}$ & $x$ & $x$ \\
\hline Piaya cayana (Linnaeus, 1766) & Squirrel Cuckoo & s1, s2 & $C, F, S, T$ & $x$ & $x$ \\
\hline Coccyzus melacoryphus Vieillot, 1817 & Dark-billed Cuckoo & s1 & C, F, S & $x$ & \\
\hline Crotophaga major Gmelin, 1788 & Greater Ani & $\mathrm{O}, \mathrm{v}$ & $\mathrm{F}, \mathrm{V}$ & & $x$ \\
\hline Crotophaga ani Linnaeus, 1758 & Smooth-billed Ani & $0, v$ & $M, S, V$ & & $X$ \\
\hline Tapera naevia (Linnaeus, 1766) & Striped Cuckoo & s1 & $C, F, S, V$ & $x$ & $x$ \\
\hline
\end{tabular}


(Continued)

\begin{tabular}{|c|c|c|c|c|c|}
\hline Order/Family/Species & English name & Evidence & Habitat & $\begin{array}{c}\text { Previous } \\
\text { fieldworkers }\end{array}$ & $\begin{array}{l}\text { Present } \\
\text { study }\end{array}$ \\
\hline Dromococcyx pavoninus Pelzeln, 1870 & Pavonine Cuckoo & $0, v$ & $C, F, T$ & & $x$ \\
\hline \multicolumn{6}{|l|}{ Strigiformes } \\
\hline Strigidae & Owls & & & & \\
\hline Megascops choliba (Vieillot, 1817) & Tropical Screech-Owl & s2 & C, F, S, T & & $x$ \\
\hline Pulsatrix perspicillata (Latham, 1790) & Spectacled Owl & s1 & $\mathrm{F}, \mathrm{T}$ & $x$ & \\
\hline Asio stygius (Wagler, 1832) & Stygian Owl & o & C, F, S & & $x$ \\
\hline \multicolumn{6}{|l|}{ Caprimulgiformes } \\
\hline Nyctibiidae & Potoos & & & & \\
\hline Nyctibius grandis (Gmelin, 1789) & Great Potoo & s1 & $\mathrm{F}, \mathrm{T}$ & $x$ & \\
\hline Nyctibius griseus (Gmelin, 1789) & Common Potoo & s2 & $C, F, S, T$ & & $x$ \\
\hline Caprimulgidae & Nightjars & & & & \\
\hline Chordeiles pusillus Gould, 1861 & Least Nighthawk & s1, s2 & $S$ & & $x$ \\
\hline Chordeiles acutipennis (Hermann, 1783) & Lesser Nighthawk & s1, s2 & $C, S$ & $x$ & $x$ \\
\hline Nyctiprogne leucopyga (Spix, 1825) & Band-tailed Nighthawk & s1 & $F, L, V$ & $x$ & \\
\hline Nyctidromus albicollis (Gmelin, 1789) & Pauraque & s1 & $\begin{array}{c}C, F, M, S \\
T, V\end{array}$ & $x$ & $x$ \\
\hline Caprimulgus rufus Boddaert, 1783 & Rufous Nightjar & $\mathrm{t}$ & $C, S$ & & $x$ \\
\hline Hydropsalis climacocerca (Tschudi, 1844) & Ladder-tailed Nightjar & s1 & $\mathrm{F}$ & $x$ & \\
\hline Hydropsalis torquata (Gmelin, 1789) & Scissor-tailed Nightjar & s1 & C, S & & $x$ \\
\hline \multicolumn{6}{|l|}{ Apodiformes } \\
\hline Apodidae & Swifts & & & & \\
\hline Chaetura brachyura (Jardine, 1846) & Short-tailed Swift & ○ & $\begin{array}{c}C, F, L, M, S, \\
T, V\end{array}$ & & $x$ \\
\hline Tachornis squamata (Cassin, 1853) & Fork-tailed Palm-Swift & s1 & $\begin{array}{c}\text { C, F, L, M, S, } \\
\text { T, } \bigvee\end{array}$ & $x$ & \\
\hline Trochilidae & Hummingbirds & & & & \\
\hline Phaethornis rupurumii Boucard, 1892 & Streak-throated Hermit & s1, s4, t & $C, F, S, T$ & $x$ & $x$ \\
\hline Phaethornis ruber (Linnaeus, 1758) & Reddish Hermit & s1 & $\mathrm{C}, \mathrm{F}, \mathrm{T}$ & & $x$ \\
\hline Eupetomena macroura (Gmelin, 1788) & Swallow-tailed Hummingbird & s1, s2 & $\begin{array}{c}\mathrm{C}, \mathrm{F}, \mathrm{M}, \mathrm{S}, \\
\mathrm{T}, \mathrm{V}\end{array}$ & $x$ & $x$ \\
\hline Anthracothorax viridigula (Boddaert, 1783) & Green-throated Mango & s1 & $\mathrm{F}, \mathrm{V}$ & $x$ & $x$ \\
\hline Anthracothorax nigricollis (Vieillot, 1817) & Black-throated Mango & s1 & $C, F, S, T, V$ & $x$ & \\
\hline Avocettula recurvirostris (Swainson, 1822) & Fiery-tailed Awlbill & s1 & $\mathrm{C}, \mathrm{T}$ & $x$ & \\
\hline Lophornis ornatus (Boddaert, 1783) & Tufted Coquette & s1 & $\mathrm{F}, \mathrm{T}$ & $x$ & \\
\hline Chlorostilbon notatus (Reich, 1793) & Blue-chinned Sapphire & s1 & $C, F$ & $x$ & \\
\hline Thalurania furcata (Gmelin, 1788) & Fork-tailed Woodnymph & s1 & $\mathrm{C}, \mathrm{F}, \mathrm{T}$ & & $x$ \\
\hline
\end{tabular}


(Continued)

\begin{tabular}{|c|c|c|c|c|c|}
\hline Order/Family/Species & English name & Evidence & Habitat & $\begin{array}{c}\text { Previous } \\
\text { fieldworkers }\end{array}$ & $\begin{array}{l}\text { Present } \\
\text { study }\end{array}$ \\
\hline Hylocharis sapphirina (Gmelin, 1788) & Rufous-throated Sapphire & s1 & $C, T$ & $x$ & \\
\hline Amazilia versicolor (Vieillot, 1818) & Versicolored Emerald & $p$ & $\mathrm{~T}, \mathrm{~V}$ & & $x$ \\
\hline Amazilia fimbriata (Gmelin, 1788) & Glittering-throated Emerald & s1, s2 & $\mathrm{S}, \mathrm{T}$ & $x$ & $x$ \\
\hline \multicolumn{6}{|l|}{ Trogoniformes } \\
\hline Trogonidae & Trogons & & & & \\
\hline Trogon melanurus Swainson, 1838 & Black-tailed Trogon & s1 & $C, F, T$ & $x$ & \\
\hline Trogon viridis Linnaeus, 1766 & White-tailed Trogon & s1, s2, p & $C, F, T$ & $x$ & $x$ \\
\hline \multicolumn{6}{|l|}{ Coraciiformes } \\
\hline Alcedinidae & Kingfishers & & & & \\
\hline Megaceryle torquata (Linnaeus, 1766) & Ringed Kingisher & o & $\mathrm{L}$ & & $x$ \\
\hline Chloroceryle amazona (Latham, 1790) & Amazon Kingisher & s1 & $\mathrm{L}$ & $x$ & $x$ \\
\hline Chloroceryle aenea (Pallas, 1764) & American Pygmy Kingfisher & s1 & $F, L$ & $x$ & \\
\hline Chloroceryle americana (Gmelin, 1788) & Green Kingfisher & s1 & $\mathrm{L}$ & $x$ & $x$ \\
\hline Momotidae & Motmots & & & & \\
\hline Momotus momota (Linnaeus, 1766) & Blue-crowned Motmot & s1 & $\mathrm{F}, \mathrm{T}$ & $x$ & $x$ \\
\hline \multicolumn{6}{|l|}{ Galbuliformes } \\
\hline Galbulidae & Jacamars & & & & \\
\hline Brachygalba lugubris (Swainson, 1838) & Brown Jacamar & s1 & $C, T$ & $x$ & $x$ \\
\hline Galbula ruficauda Cuvier, 1816 & Rufous-tailed Jacamar & s1 & $\mathrm{F}, \mathrm{T}$ & $x$ & \\
\hline Galbula galbula (Linnaeus, 1766) & Green-tailed Jacamar & s1, s2, p & $\mathrm{F}, \mathrm{T}$ & $x$ & $x$ \\
\hline Bucconidae & Puffbirds & & & & \\
\hline Notharchus ordii (Cassin, 1851) & Brown-banded Puffbird & s1 & $T$ & $x$ & \\
\hline Notharchus tectus (Boddaert, 1783) & Pied Puffbird & s1, s2 & $T$ & $x$ & $x$ \\
\hline Bucco tamatia Gmelin, 1788 & Spotted Puffbird & s1, s2, p & $\mathrm{F}, \mathrm{T}$ & $x$ & $x$ \\
\hline Monasa nigrifrons (Spix, 1824) & Black-fronted Nunbird & s1 & $\mathrm{F}, \mathrm{T}$ & $x$ & \\
\hline $\begin{array}{l}\text { Monasa morphoeus } \\
\text { (Hahn \& Küster, 1823) }\end{array}$ & White-fronted Nunbird & s1 & T & $x$ & \\
\hline Chelidoptera tenebrosa (Pallas, 1782) & Swallow-wing & s1 & $C, F, S, T, V$ & $x$ & $x$ \\
\hline \multicolumn{6}{|l|}{ Piciformes } \\
\hline Ramphastidae & Toucans and Aracaris & & & & \\
\hline Ramphastos toco Statius Muller, 1776 & Toco Toucan & s1 & $S, V$ & $x$ & $x$ \\
\hline Ramphastos tucanus Linnaeus, 1758 & Red-billed Toucan & o & $T$ & & $x$ \\
\hline Pteroglossus bitorquatus Vigors, 1826 & Red-necked Aracari & s1 & $T$ & $x$ & \\
\hline Pteroglossus aracari (Linnaeus, 1758) & Black-necked Aracari & s1 & $\mathrm{F}, \mathrm{T}$ & $x$ & $x$ \\
\hline Picidae & Woodpeckers & & & & \\
\hline Picumnus exilis (Lichtenstein, 1823) & Golden-spangled Piculet & s2 & $C, T$ & & $x$ \\
\hline
\end{tabular}


(Continued)

\begin{tabular}{|c|c|c|c|c|c|}
\hline Order/Family/Species & English name & Evidence & Habitat & $\begin{array}{c}\text { Previous } \\
\text { fieldworkers }\end{array}$ & $\begin{array}{l}\text { Present } \\
\text { study }\end{array}$ \\
\hline Picumnus cirratus Temminck, 1825 & White-barred Piculet & $\mathrm{s} 1, \mathrm{t}$ & $\mathrm{F}, \mathrm{T}$ & $x$ & $x$ \\
\hline Melanerpes candidus (Otto, 1796) & White Woodpecker & s1 & $M, S, V$ & $x$ & \\
\hline Veniliornis cassini (Malherbe, 1862) & Golden-collared Woodpecker & s1 & $\mathrm{T}$ & $x$ & \\
\hline Veniliornis passerinus (Linnaeus, 1766) & Little Woodpecker & s1, s2 & $C, F$ & $x$ & $x$ \\
\hline Colaptes punctigula (Boddaert, 1783) & Spot-breasted Woodpecker & s1 & $\mathrm{F}, \mathrm{T}$ & $x$ & \\
\hline Colaptes campestris (Vieillot, 1818) & Campo Flicker & s1 & S & $x$ & $x$ \\
\hline Celeus flavescens (Gmelin, 1788) & Blond-crested Woodpecker & $\mathrm{s} 1, \mathrm{t}$ & $C, T$ & $x$ & $x$ \\
\hline Dryocopus lineatus (Linnaeus, 1766) & Lineated Woodpecker & o & $C, F, S, T, V$ & & $x$ \\
\hline $\begin{array}{l}\text { Campephilus melanoleucos } \\
\text { (Gmelin, 1788) }\end{array}$ & Crimson-crested Woodpecker & s1 & $C, F, S, T, V$ & $x$ & $x$ \\
\hline \multicolumn{6}{|l|}{ Passeriformes } \\
\hline Thamnophilidae & Typical Antbirds & & & & \\
\hline Taraba major (Vieillot, 1816) & Great Antshrike & s1 & $C, F$ & $x$ & $x$ \\
\hline Sakesphorus luctuosus (Lichtenstein, 1823) & Glossy Antshrike & s1 & $\mathrm{F}$ & $x$ & $x$ \\
\hline Thamnophilus doliatus (Linnaeus, 1764) & Barred Antshrike & s1, s2 & $C, F$ & $x$ & $x$ \\
\hline Thamnophilus nigrocinereus Sclater, 1855 & Blackish-gray Antshrike & s1 & $\mathrm{F}$ & $x$ & \\
\hline Thamnophilus punctatus (Shaw, 1809) & Northern Slaty-Antshrike & $s 1, \mathrm{t}$ & $C, T$ & $x$ & $x$ \\
\hline Myrmotherula axillaris (Vieillot, 1817) & White-flanked Antwren & s1 & $C, F, T$ & $x$ & $x$ \\
\hline Myrmotherula assimilis Pelzeln, 1868 & Leaden Antwren & s1 & $\mathrm{F}$ & $x$ & \\
\hline Formicivora grisea (Boddaert, 1783) & White-fringed Antwren & $s 1, s 2, p$ & $C, S$ & $x$ & $x$ \\
\hline Formicivora rufa (Wied, 1831) & Rusty-backed Antwren & s1, p & S & $x$ & $x$ \\
\hline Cercomacra tyrannina (Sclater, 1855) & Dusky Antbird & $s 1, t$ & $C, T$ & $x$ & $x$ \\
\hline Cercomacra laeta Todd, 1920 & Willis' Antbird & s1 & $\mathrm{F}, \mathrm{T}$ & & $x$ \\
\hline Myrmoborus lugubris (Cabanis, 1847) & Ash-breasted Antbird & s1 & $\mathrm{F}$ & $x$ & \\
\hline $\begin{array}{l}\text { Hypocnemoides melanopogon } \\
\text { (Sclater, 1857) }\end{array}$ & Black-chinned Antbird & s1 & $\mathrm{F}$ & $x$ & \\
\hline Sclateria naevia (Gmelin, 1788) & Silvered Antbird & $\mathrm{v}$ & $\mathrm{F}$ & & $x$ \\
\hline Myrmeciza longipes (Swainson, 1825) & White-bellied Antbird & $s 1, s 2, t$ & C & $x$ & $x$ \\
\hline Formicariidae & Ground-antbirds & & & & \\
\hline Formicarius colma Boddaert, 1783 & Rufous-capped Antthrush & s1 & $\mathrm{C}, \mathrm{F}, \mathrm{T}$ & $x$ & $x$ \\
\hline $\begin{array}{l}\text { Formicarius analis } \\
\text { (d'Orbigny \& Lafresnaye, 1837) }\end{array}$ & Black-faced Antthrush & s1 & $\mathrm{T}$ & $x$ & \\
\hline Dendrocolaptidae & Woodcreepers & & & & \\
\hline Dendrocincla fuliginosa (Vieillot, 1818) & Plain-brown Woodcreeper & $\mathrm{s} 1, \mathrm{t}$ & $\mathrm{C}, \mathrm{F}, \mathrm{T}$ & & $x$ \\
\hline Nasica longirostris (Vieillot, 1818) & Long-billed Woodcreeper & s1 & $\mathrm{F}$ & $x$ & \\
\hline Dendroplex picus (Gmelin, 1788) & Straight-billed Woodcreeper & $s 1, s 2, p$ & C, F, S & $x$ & $x$ \\
\hline
\end{tabular}


(Continued)

\begin{tabular}{|c|c|c|c|c|c|}
\hline Order/Family/Species & English name & Evidence & Habitat & $\begin{array}{c}\text { Previous } \\
\text { fieldworkers }\end{array}$ & $\begin{array}{l}\text { Present } \\
\text { study }\end{array}$ \\
\hline $\begin{array}{l}\text { Xiphorhynchus obsoletus } \\
\text { (Lichtenstein, 1820) }\end{array}$ & Striped Woodcreeper & s1 & $C, F, T$ & $x$ & \\
\hline $\begin{array}{l}\text { Xiphorhynchus guttatus } \\
\text { (Lichtenstein, 1820) }\end{array}$ & Buff-throated Woodcreeper & $s 1, t$ & $\mathrm{~F}, \mathrm{~T}$ & $x$ & $x$ \\
\hline $\begin{array}{l}\text { Lepidocolaptes angustirostris } \\
\text { (Vieillot, 1818) }\end{array}$ & Narrow-billed Woodcreeper & s1 & S & $x$ & $x$ \\
\hline $\begin{array}{l}\text { Campylorhamphus trochilirostris } \\
\text { (Lichtenstein, 1820) }\end{array}$ & Red-billed Scythebill & s1 & $\mathrm{F}, \mathrm{T}$ & $x$ & \\
\hline $\begin{array}{l}\text { Campylorhamphus procurvoides } \\
\text { (Lafresnaye, 1850) }\end{array}$ & Curve-billed Scythebill & s1 & $\mathrm{T}$ & $x$ & \\
\hline Furnariidae & Ovenbirds & & & & \\
\hline Furnarius figulus (Lichtenstein, 1823) & Wing-banded Hornero & s1 & V & $x$ & \\
\hline Furnarius minor Pelzeln, 1858 & Lesser Hornero & s1 & V & $x$ & \\
\hline Synallaxis albescens Temminck, 1823 & Pale-breasted Spinetail & $\mathrm{s} 1, \mathrm{~s} 2, \mathrm{t}$ & S & $x$ & $x$ \\
\hline Synallaxis rutilans Temminck, 1823 & Ruddy Spinetail & s1 & $\mathrm{T}$ & $x$ & \\
\hline Synallaxis gujanensis (Gmelin, 1789) & Plain-crowned Spinetail & s1 & $\mathrm{F}$ & $x$ & $x$ \\
\hline Cranioleuca vulpina (Pelzeln, 1856) & Rusty-backed Spinetail & $\mathrm{s} 1, \mathrm{t}$ & $\mathrm{F}$ & $x$ & $x$ \\
\hline Cranioleuca muelleri (Hellmayr, 1911) & Scaled Spinetail & s1 & $\mathrm{F}$ & $x$ & \\
\hline Certhiaxis cinnamomeus (Gmelin, 1788) & Yellow-chinned Spinetail & s1 & $L, V$ & $x$ & $x$ \\
\hline Certhiaxis mustelinus (Sclater, 1874) & Red-and-white Spinetail & s1 & $L, V$ & $x$ & \\
\hline Berlepschia rikeri (Ridgway, 1886) & Point-tailed Palmcreeper & $\mathrm{t}$ & $\mathrm{V}$ & & $x$ \\
\hline Xenops minutus (Sparrman, 1788) & Plain Xenops & $\mathrm{t}$ & $\mathrm{F}, \mathrm{T}$ & & $x$ \\
\hline Tyrannidae & Tyrant-flycatchers & & & & \\
\hline Lophotriccus galeatus (Boddaert, 1783) & Helmeted Pygmy-Tyrant & $\mathrm{t}$ & C, T & & $x$ \\
\hline Poecilotriccus fumifrons (Hartlaub, 1853) & Smoky-fronted Tody-Flycatcher & s1 & $\mathrm{C}, \mathrm{T}$ & & $x$ \\
\hline $\begin{array}{l}\text { Todirostrum maculatum } \\
\text { (Desmarest, 1806) }\end{array}$ & Spotted Tody-Flycatcher & s1 & $F, M$ & $x$ & $x$ \\
\hline Todirostrum cinereum (Linnaeus, 1766) & Common Tody-Flycatcher & s1, s2 & C, S & $x$ & $x$ \\
\hline Tyrannulus elatus (Latham, 1790) & Yellow-crowned Tyrannulet & s1 & $\mathrm{C}, \mathrm{F}, \mathrm{T}$ & $x$ & $x$ \\
\hline Myiopagis gaimardii (d'Orbigny, 1839) & Forest Elaenia & O & $\mathrm{C}, \mathrm{F}, \mathrm{T}$ & & $x$ \\
\hline Myiopagis flavivertex (Sclater, 1887) & Yellow-crowned Elaenia & s1 & $\mathrm{F}$ & $x$ & \\
\hline Myiopagis viridicata (Vieillot, 1817) & Greenish Elaenia & O & C, T & & $x$ \\
\hline Elaenia flavogaster (Thunberg, 1822) & Yellow-bellied Elaenia & s1, s2 & S & $x$ & $x$ \\
\hline Elaenia pelzelni Berlepsch, 1907 & Brownish Elaenia & s1 & $\mathrm{F}, \mathrm{V}$ & $x$ & \\
\hline Elaenia cristata Pelzeln, 1868 & Plain-crested Elaenia & s1, s2 & S & $x$ & $x$ \\
\hline Elaenia chiriquensis Lawrence, 1865 & Lesser Elaenia & $\mathrm{s} 1, \mathrm{~s} 2, \mathrm{t}$ & S & & $x$ \\
\hline
\end{tabular}


(Continued)

\begin{tabular}{|c|c|c|c|c|c|}
\hline Order/Family/Species & English name & Evidence & Habitat & $\begin{array}{l}\text { Previous } \\
\text { fieldworkers }\end{array}$ & $\begin{array}{l}\text { Present } \\
\text { study }\end{array}$ \\
\hline $\begin{array}{l}\text { Camptostoma obsoletum } \\
\text { (Temminck, 1824) }\end{array}$ & Southern Beardless-Tyrannulet & s1 & $C, M, S, V$ & $x$ & $x$ \\
\hline Suiriri suiriri (Vieillot, 1818) & Suiriri Flycatcher & $\mathrm{s} 1, \mathrm{~s} 2, \mathrm{t}$ & $\mathrm{S}$ & $x$ & $x$ \\
\hline Phaeomyias murina (Spix, 1825) & Mouse-colored Tyrannulet & s1, s2 & $C, S$ & $x$ & $x$ \\
\hline Sublegatus modestus (Wied, 1831) & Southern Scrub-Flycatcher & s1 & $\mathrm{S}$ & $x$ & $x$ \\
\hline $\begin{array}{l}\text { Tolmomyias poliocephalus } \\
\text { (Taczanowski, 1884) }\end{array}$ & Gray-crowned Flycatcher & $0, v$ & $\mathrm{~F}, \mathrm{~T}$ & & $x$ \\
\hline Tolmomyias flaviventris (Wied, 1831) & Yellow-breasted Flycatcher & s1, s2 & C & $x$ & $x$ \\
\hline Cnemotriccus fuscatus (Wied, 1831) & Fuscous Flycatcher & s1, s2 & $\mathrm{C}$ & & $x$ \\
\hline Pyrocephalus rubinus (Boddaert, 1783) & Vermilion Flycatcher & s1 & $M, S, V$ & $x$ & \\
\hline Knipolegus poecilocercus (Pelzeln, 1868) & Amazonian Black-Tyrant & s1 & $\mathrm{F}$ & $x$ & \\
\hline Xolmis velatus (Lichtenstein, 1823) & White-rumped Monjita & s1, s2 & $\mathrm{S}$ & $x$ & $x$ \\
\hline Fluvicola albiventer (Spix, 1825) & Black-backed Water-Tyrant & s1 & $L, V$ & $x$ & \\
\hline $\begin{array}{l}\text { Arundinicola leucocephala } \\
\text { (Linnaeus, 1764) }\end{array}$ & White-headed Marsh-Tyrant & s1 & $L, V$ & $x$ & \\
\hline Legatus leucophaius (Vieillot, 1818) & Piratic Flycatcher & s1, s2 & $C, F, M, T, V$ & $x$ & $x$ \\
\hline Myiozetetes cayanensis (Linnaeus, 1766) & Rusty-margined Flycatcher & s2 & V & & $x$ \\
\hline Myiozetetes similis (Spix, 1825) & Social Flycatcher & s1 & $\begin{array}{c}\text { C, F, M, S, } \\
T, V\end{array}$ & $x$ & \\
\hline Pitangus sulphuratus (Linnaeus, 1766) & Great Kiskadee & s1 & $\begin{array}{c}\text { C, F, M, S, } \\
T, V\end{array}$ & $x$ & $x$ \\
\hline Philohydor lictor (Lichtenstein, 1823) & Lesser Kiskadee & s1 & $L, V$ & & $x$ \\
\hline Conopias trivirgatus (Wied, 1831) & Three-striped Flycatcher & s1, s2, p & C, F, S, T & & $x$ \\
\hline $\begin{array}{l}\text { Myiodynastes maculatus } \\
\text { (Statius Muller, 1776) }\end{array}$ & Streaked Flycatcher & s1 & $\begin{array}{c}C, F, M, S \\
T, V\end{array}$ & $x$ & $x$ \\
\hline Megarynchus pitangua (Linnaeus, 1766) & Boat-billed Flycatcher & $\mathrm{s} 2, \mathrm{t}$ & $\begin{array}{c}\text { C, F, M, S, } \\
T, V\end{array}$ & & $x$ \\
\hline Tyrannopsis sulphurea (Spix, 1825) & Sulphury Flycatcher & $p$ & $\mathrm{~V}$ & & $x$ \\
\hline Empidonomus varius (Vieillot, 1818) & Variegated Flycatcher & ० & $\begin{array}{c}\text { C, F, M, S, } \\
T, V\end{array}$ & & $x$ \\
\hline Tyrannus albogularis Burmeister, 1856 & White-throated Kingbird & s1 & $\begin{array}{c}C, F, M, S \\
T, V\end{array}$ & $x$ & \\
\hline Tyrannus melancholicus Vieillot, 1819 & Tropical Kingbird & o & $\begin{array}{c}\mathrm{C}, \mathrm{F}, \mathrm{M}, \mathrm{S} \\
\mathrm{T}, \mathrm{V}\end{array}$ & & $x$ \\
\hline Tyrannus savana Vieillot, 1808 & Fork-tailed Flycatcher & s1, s2 & S & $x$ & $x$ \\
\hline Casiornis rufus (Vieillot, 1816) & Rufous Casiornis & s1 & $\mathrm{C}, \mathrm{T}$ & $x$ & $x$ \\
\hline
\end{tabular}


(Continued)

\begin{tabular}{|c|c|c|c|c|c|}
\hline Order/Family/Species & English name & Evidence & Habitat & $\begin{array}{c}\text { Previous } \\
\text { fieldworkers }\end{array}$ & $\begin{array}{l}\text { Present } \\
\text { study }\end{array}$ \\
\hline Casiornis fuscus Sclater \& Salvin, 1873 & Ash-throated Casiornis & s2 & $C, T$ & & $x$ \\
\hline $\begin{array}{l}\text { Myiarchus tuberculifer (d'Orbigny \& } \\
\text { Lafresnaye, 1837) }\end{array}$ & Dusky-capped Flycatcher & $\mathrm{o}, \mathrm{v}$ & $C, F, T$ & & $x$ \\
\hline Myiarchus ferox (Gmelin, 1789) & Short-crested Flycatcher & s1, s2 & $\begin{array}{l}C, F, M, S \\
T, V\end{array}$ & X & $x$ \\
\hline $\begin{array}{l}\text { Myiarchus tyrannulus } \\
\text { (Statius Muller, 1776) }\end{array}$ & Brown-crested Flycatcher & s1, s2 & $\mathrm{C}, \mathrm{S}, \mathrm{T}$ & X & $x$ \\
\hline Attila cinnamomeus (Gmelin, 1789) & Cinnamon Attila & s1 & $C, F, T$ & $x$ & \\
\hline Attila bolivianus Lafresnaye, 1848 & Dull-capped Attila & s1 & $\mathrm{F}$ & $x$ & \\
\hline Attila spadiceus (Gmelin, 1789) & Bright-rumped Attila & s1 & $\mathrm{T}$ & $x$ & \\
\hline Cotingidae & Cotingas & & & & \\
\hline Gymnoderus foetidus (Linnaeus, 1758) & Bare-necked Fruitcrow & s1 & $\mathrm{F}, \mathrm{T}$ & $x$ & \\
\hline $\begin{array}{l}\text { Perissocephalus tricolor } \\
\text { (Statius Muller, 1776) }\end{array}$ & Capuchinbird & s1 & $\mathrm{T}$ & $x$ & \\
\hline Pipridae & Manakins & & & & \\
\hline Neopelma pallescens (Lafresnaye, 1853) & Pale-bellied Tyrant-Manakin & $s 1, s 2$ & C & & $x$ \\
\hline Manacus manacus (Linnaeus, 1766) & White-bearded Manakin & $s 1, s 2, p$ & $C, T$ & $x$ & $x$ \\
\hline Chiroxiphia pareola (Linnaeus, 1766) & Blue-backed Manakin & s1 & $C, T$ & $x$ & $x$ \\
\hline Pipra aureola (Linnaeus, 1758) & Crimson-hooded Manakin & $s 1, s 2, p, t$ & $C, F, T$ & $x$ & $x$ \\
\hline Pipra erythrocephala (Linnaeus, 1758) & Golden-headed Manakin & s1 & $C, T$ & $x$ & \\
\hline Tityridae & Tityras & & & & \\
\hline Schiffornis olivacea (Ridgway, 1906) & Olivaceus Schiffornis & $\circ$ & $C, T$ & & $x$ \\
\hline Tityra cayana (Linnaeus, 1766) & Black-tailed Tityra & s1 & C, F, T & $x$ & \\
\hline Tityra semifasciata (Spix, 1825) & Masked Tityra & s1 & $\mathrm{T}$ & $x$ & \\
\hline Pachyramphus rufus (Boddaert, 1783) & Cinereous Becard & s1 & $\mathrm{F}, \mathrm{T}$ & $x$ & \\
\hline $\begin{array}{l}\text { Pachyramphus castaneus } \\
\text { (Jardine \& Selby, 1827) }\end{array}$ & Chestnut-crowned Becard & s1 & $\mathrm{T}$ & $x$ & \\
\hline $\begin{array}{l}\text { Pachyramphus polychopterus } \\
\text { (Vieillot, 1818) }\end{array}$ & White-winged Becard & s1 & $C, T$ & $x$ & $X$ \\
\hline Vireonidae & Vireos & & & & \\
\hline Cyclarhis gujanensis (Gmelin, 1789) & Rufous-browed Peppershrike & s1, s2 & C, F, S, T & $x$ & $x$ \\
\hline Vireo olvaceus (Linnaeus, 1766) & Red-eyed Vireo & $s 1, s 2$ & $\mathrm{C}, \mathrm{F}, \mathrm{T}$ & $x$ & $x$ \\
\hline Hylophilus pectoralis Sclater, 1866 & Ashy-headed Greenlet & $s 1, s 2, p$ & $C, F, S, T$ & $x$ & $x$ \\
\hline Corvidae & Crows and Jays & & & & \\
\hline Cyanocorax cayanus (Linnaeus, 1766) & Cayenne Jay & $\mathrm{t}$ & $C, T$ & & $x$ \\
\hline Hirundinidae & Swallows & & & & \\
\hline
\end{tabular}


(Continued)

\begin{tabular}{|c|c|c|c|c|c|}
\hline Order/Family/Species & English name & Evidence & Habitat & $\begin{array}{c}\text { Previous } \\
\text { fieldworkers }\end{array}$ & $\begin{array}{l}\text { Present } \\
\text { study }\end{array}$ \\
\hline Progne tapera (Vieillot, 1817) & Brown-chested Martin & s1 & $F, L, M, S, V$ & $x$ & \\
\hline Progne chalybea (Gmelin, 1789) & Gray-breasted Martin & s1 & $F, L, M, S, V$ & $x$ & \\
\hline Tachycineta albiventer (Boddaert, 1783) & White-winged Swallow & s3, p & $L, V$ & & $x$ \\
\hline Riparia riparia (Linnaeus, 1758) & Bank Swallow & o & $\mathrm{L}$ & & $x$ \\
\hline Hirundo rustica Linnaeus, 1758 & Barn Swallow & $\mathrm{p}$ & $L, M, S$ & & $x$ \\
\hline Troglodytidae & Wrens & & & & \\
\hline Troglodytes musculus Naumann, 1823 & Southern House-Wren & s1 & $M, S$ & $x$ & $x$ \\
\hline Cantorchilus leucotis (Lafresnaye, 1845) & Buff-breasted Wren & s1, s2, p & $\mathrm{F}$ & $x$ & $x$ \\
\hline Donacobiidae & Donacobius & & & & \\
\hline Donacobius atricapilla (Linnaeus, 1766) & Black-capped Donacobius & s1 & $L, V$ & $x$ & \\
\hline Polioptilidae & Gnatcatchers & & & & \\
\hline Polioptila plumbea (Gmelin, 1788) & Tropical Gnatcatcher & s1, s2 & $C, F, V$ & $x$ & $x$ \\
\hline Turdidae & Thrushes & & & & \\
\hline Turdus nudigenis Lafresnaye, 1848 & Bare-eyed Thrush & $s 1, s 2, p, t$ & C, F, T & & $x$ \\
\hline Turdus leucomelas Vieillot, 1818 & Pale-breasted Thrush & $s 1, s 2$ & $C, F, M, S$ & $x$ & $x$ \\
\hline Turdus fumigatus Lichtenstein, 1823 & Cocoa Thrush & s1 & $\mathrm{F}, \mathrm{T}$ & & $x$ \\
\hline Turdus ignobilis Sclater, 1858 & Black-billed Thrush & s1 & $C, T$ & $x$ & \\
\hline Mimidae & Mockingbirds & & & & \\
\hline Mimus saturninus (Lichtenstein, 1823) & Chalk-browed Mockingbird & s1, s2 & $\mathrm{S}$ & $x$ & $x$ \\
\hline Coerebidae & Bananaquits & & & & \\
\hline $\begin{array}{l}\text { Coereba flaveola } \\
\text { (Linnaeus, 1758) }\end{array}$ & Bananaquit & s1, s2 & $\begin{array}{c}C, F, M, S, \\
T, V\end{array}$ & $x$ & $x$ \\
\hline Thraupidae & Tanagers & & & & \\
\hline Saltator maximus (Statius Muller, 1776) & Buff-throated Saltator & s1, s2 & $C, T$ & $x$ & $x$ \\
\hline Saltator coerulescens Vieillot, 1817 & Grayish Saltator & $\circ$ & $\mathrm{F}, \mathrm{V}$ & & $x$ \\
\hline Schistochlamys melanopis (Latham, 1790) & Black-faced Tanager & $\circ$ & $S$ & & $x$ \\
\hline Nemosia pileata (Boddaert, 1783) & Hooded Tanager & s1 & C, F, S, V & $x$ & $x$ \\
\hline Tachyphonus rufus (Boddaert, 1783) & White-lined Tanager & s2 & C, S & & $x$ \\
\hline Ramphocelus nigrogularis (Spix, 1825) & Masked Crimson Tanager & s1 & $F, V$ & $x$ & \\
\hline Ramphocelus carbo (Pallas, 1764) & Silver-beaked Tanager & $s 1, s 2$ & $C, F, M, T, V$ & $x$ & $x$ \\
\hline Thraupis episcopus (Linnaeus, 1766) & Blue-gray Tanager & s2 & C, F, M, S, T & & $x$ \\
\hline Thraupis palmarum (Wied, 1823) & Palm Tanager & s1 & $\begin{array}{c}C, F, M, S, \\
T, V\end{array}$ & $x$ & $x$ \\
\hline Tangara mexicana (Linnaeus, 1766) & Turquoise Tanager & s1 & $\mathrm{C}, \mathrm{F}, \mathrm{T}$ & $x$ & \\
\hline Tangara cayana (Linnaeus, 1766) & Burnished-buff Tanager & $s 1, s 2$ & $\begin{array}{c}C, F, M, S, \\
T, V\end{array}$ & $x$ & $x$ \\
\hline
\end{tabular}


(Continued)

\begin{tabular}{|c|c|c|c|c|c|}
\hline Order/Family/Species & English name & Evidence & Habitat & $\begin{array}{l}\text { Previous } \\
\text { fieldworkers }\end{array}$ & $\begin{array}{l}\text { Present } \\
\text { study }\end{array}$ \\
\hline Dacnis cayana (Linnaeus, 1766) & Blue Dacnis & s1 & $\begin{array}{c}C, F, M, S \\
T, V\end{array}$ & $x$ & $x$ \\
\hline Cyanerpes cyaneus (Linnaeus, 1766) & Red-legged Honeycreeper & s1 & $C, T$ & $x$ & \\
\hline Conirostrum speciosum (Temminck, 1824) & Chestnut-vented Conebill & s1 & $C, F, S, T$ & $x$ & $x$ \\
\hline Conirostrum bicolor (Vieillot, 1809) & Bicolored Conebill & s1 & $\mathrm{F}$ & $x$ & \\
\hline Emberizidae & Seedeaters & & & & \\
\hline Zonotrichia capensis (Statius Muller, 1776) & Rufous-collared Sparrow & s1, s2 & M, S & $x$ & $x$ \\
\hline Ammodramus humeralis (Bosc, 1792) & Grassland Sparrow & s1, s2 & M, S & $x$ & $x$ \\
\hline Sicalis citrina Pelzeln, 1870 & Stripe-tailed Yellow-Finch & s1 & $S$ & & $x$ \\
\hline Sicalis columbiana Cabanis, 1851 & Orange-fronted Yellow-finch & s1 & $F, V$ & $x$ & \\
\hline Sicalis luteola (Sparrman, 1789) & Grassland Yellow-Finch & s1 & $M, S, V$ & $x$ & \\
\hline Volatinia jacarina (Linnaeus, 1766) & Blue-black Grassquit & $\vee$ & $M, S, V$ & & $x$ \\
\hline Sporophila plumbea (Wied, 1830) & Plumbeous Seedeater & s1 & S, V & & $x$ \\
\hline Sporophila americana (Gmelin, 1789) & Wing-barred Seedeater & s1 & $M, V$ & $x$ & \\
\hline Sporophila lineola (Linnaeus, 1758) & Lined Seedeater & s1 & $M, V$ & & $x$ \\
\hline Sporophila nigricollis (Vieillot, 1823) & Yellow-bellied Seedeater & s1, s2 & $M, S, V$ & $x$ & $x$ \\
\hline Sporophila castaneiventris Cabanis, 1849 & Chestnut-bellied Seedeater & s1 & $\vee$ & $x$ & \\
\hline Sporophila angolensis (Linnaeus, 1766) & Chestnut-bellied Seed-Finch & s1 & S, V & & $x$ \\
\hline Arremon taciturnus (Hermann, 1783) & Pectoral Sparrow & s1, s2 & $\mathrm{F}, \mathrm{T}$ & & $x$ \\
\hline Paroaria gularis (Linnaeus, 1766) & Red-capped Cardinal & s1 & $F, V$ & $x$ & $x$ \\
\hline Cardinalidae & Cardinals & & & & \\
\hline Piranga flava (Vieillot, 1822) & Hepatic-Tanager & s1 & $\mathrm{S}$ & $x$ & \\
\hline Cyanoloxia cyanoides (Lafresnaye, 1847) & Blue-black Grosbeak & s1 & $\mathrm{F}, \mathrm{T}$ & $x$ & $x$ \\
\hline Parulidae & New World Warblers & & & & \\
\hline Phaeothlypis mesoleuca (Sclater, 1866) & Riverside Warbler & s1 & $\mathrm{F}, \mathrm{T}$ & & $x$ \\
\hline Icteridae & New World Blackbirds & & & & \\
\hline Psarocolius decumanus (Pallas, 1769) & Crested Oropendola & s1, s2 & $C, F, S, T$ & $x$ & $x$ \\
\hline Procacicus solitarius (Vieillot, 1816) & Solitary Cacique & s1 & V & $x$ & \\
\hline Cacicus cela (Linnaeus, 1758) & Yellow-rumped Cacique & $s 1, t$ & $C, F, S, T, V$ & $x$ & $x$ \\
\hline Icterus croconotus (Wagler, 1829) & Orange-backed Troupial & s1 & V & $x$ & \\
\hline $\begin{array}{l}\text { Gymnomystax mexicanus } \\
\text { (Linnaeus, 1766) }\end{array}$ & Oriole Blackbird & $s 1, t$ & $\vee$ & $x$ & $x$ \\
\hline $\begin{array}{l}\text { Chrysomus icterocephalus } \\
\text { (Linnaeus, 1766) }\end{array}$ & Yellow-hooded Blackbird & s1 & V & $x$ & \\
\hline Molothrus oryzivorus (Gmelin, 1788) & Giant Cowbird & s1 & $M, V$ & $x$ & \\
\hline Molothrus bonariensis (Gmelin, 1789) & Shiny Cowbird & s1 & $M, S, V$ & $x$ & \\
\hline
\end{tabular}




\begin{tabular}{l|c|c|c|c|c}
\multicolumn{1}{c|}{ Order/Family/Species } & English name & Evidence & Habitat & $\begin{array}{c}\text { Previous } \\
\text { fieldworkers }\end{array}$ & $\begin{array}{c}\text { Present } \\
\text { study }\end{array}$ \\
\hline Sturnella militaris (Linnaeus, 1758) & Red-breasted Blackbird & $s 1$ & M, S, V & $\times$ & $\times$ \\
\hline Fringillidae & Finches & & & & \\
\hline Euphonia chlorotica (Linnaeus, 1766) & Purple-throated Euphonia & s1, s2 & $\begin{array}{c}\text { C, F, M, S, } \\
\text { T, V }\end{array}$ & $\times$ & $\times$ \\
\hline Euphonia violacea (Linnaeus, 1758) & Violaceous Euphonia & $0, v$ & F, S & & $\times$ \\
\hline Passeridae & Old World Sparrows & & & & \\
\hline Passer domesticus (Linnaeus, 1758) & House Sparrow & $\circ$ & M & & $\times$ \\
\hline
\end{tabular}


